\title{
CONSTANTINE LASCARIS, HIS MANUSCRIPTS AND HIS ETHICAL CONCERNS
}

\author{
Juan Felipe Gonzalez-Calderon \\ Universidad Nacional de Colombia \\ jfgonzalezc@unal.edu.co
}

\begin{abstract}
This article aims to examine Constantine Lascaris's work on Aristoteles' ethical corpus. We consider evidence from the textual witnesses of the Nicomachean Ethics, the Eudemian Ethics, the Magna Moralia, and some other minor ethical writings, which belonged to Lascaris, in order to reconstruct his working methods. We also explore Lascaris' own statements about virtuous life; a life devoted to the service of the common good, to philosophy and to the study of texts. For him philosophy was a way of life, rather than simply a discourse. We look at the link between written culture and philosophical life and propose further research into how Byzantine and Renaissance scholars understood their own intellectual activities to be a special kind of spiritual exercise intended to promote moral improvement in both individuals and societies.
\end{abstract}

KEYWORDS: Constantine Lascaris, Aristotle, Ethics, philosophy as a way of life, written culture.

* This article was partly funded by the research project "El autor bizantino II: Transmisión de los textos y bibliotecas", FFI2015-65118-C2-2-P, 2016-2020, Ministry of Science and Innovation, Spain.

Constantine Lascaris is a well-known figure in the realm of humanism. He is especially renowned for his Epitome octo partium orationis, a Greek language textbook issued in Milan in 1476 and the first book produced in Greek printing types. ${ }^{1}$ Without a doubt, Lascaris had a pivotal role in the teaching and learning of the ancient Greek language in Europe from the Renaissance onwards. His acquisitions, findings, transcriptions, and laborious humanist activities are also invaluable sources that are still today expanding our knowledge of ancient Greek and

\footnotetext{
${ }^{1}$ Cf. Fernández Pomar (1966) 250-251; Martínez Manzano (1997) 133; Wilson (2017) 110; Timperley (1839) 218.

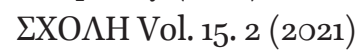

(C) Juan F. Gonzalez-Calderon, 2021

schole.ru; classics.nsu.ru

DOI:10.25205/1995-4328-2021-15-2-538-572
} 
Byzantine texts. His own library reflected a wide range of interests, and covered a variety of classical and late antique literary and scientific sources, including Homer, Hesiod, Pindar, Theocritus, Theognis, Aeschylus, Sophocles, Euripides, Aristophanes, Hippocrates, Galen, Paulus Aegineta, Euclid, Nicomachus of Gerasa, Aratus, Hermes Trismegistus, Oppian, Strabo, Plato, Aristotle, Epictetus, Isocrates, Demosthenes, Aeschines, Aelius Aristides, Aphthonius, Hermogenes, Herodotus, Thucydides, Libanius and Plutarch. Lascaris also collected, copied, read and researched many other authors during a life of hard and patient intellectual work. These authors include Church Fathers like Basil of Caesarea and Gregory of Nazianzus, as well as Byzantine scholars like Photius, Michael Psellus, Nicephorus Blemmydes, Thomas Magister, Manuel Moschopoulos, Manuel Chrysoloras and Bessarion. ${ }^{2}$ Living in the thick of the Renaissance he came across rare authors and texts, such as Quintus of Smyrna's Posthomerica, Claudian's Gigantomachy and the Orphic Argonautic, and assisted ancient scholarship once more through their preservation and popularization. In fact, it seems likely that if Lascaris' living and working conditions had been somehow more favourable, his achievements might have been deemed even more impressive. ${ }^{3}$

Until now, Lascaris' treatment of philosophical texts has not received much attention, despite the fact that careful assessment of his conjectures was deemed necessary some time ago. ${ }^{4}$ It is clear that Lascaris had a profound interest in the works of Aristotle. Aristotle was the author he copied most during his lifetime, mainly during his years of comfortable living in Milan. ${ }^{5}$ He possessed a number of manuscripts transmitting the Aristotelian corpus, and his own handwriting is identifiable in different Aristotelian textual witnesses held in our libraries and historical collections. ${ }^{6}$ Indeed, the last colophon completed by Lascaris can be

\footnotetext{
${ }^{2}$ For a complete list of Lascaris' books along with a report of manuscripts falsely ascribed in current scientific literature to his handwriting, see Martínez Manzano (1997) 3148. Cf. Fernández Pomar (1966) 221-244.

${ }^{3}$ Cf. Martínez Manzano (1997) 191-196; Wilson (2017) 136-139.

${ }^{4}$ Cf. Harlfinger (1971) 285-286.

${ }^{5}$ Cf. Fernández Pomar (1966) 248.

${ }^{6}$ Lascaris either wrote down (in full or in part) or simply annotated the Aristotelian manuscripts listed as follows (most of which also belonged to his personal library): Madrid, BNE, MSS 4549 (excerpta ex Thphr., Hist. Plant. et Aristot. Hist. An.); 4553 (Niceph. Blemmydae, Epitome physica; Aristot., Phy., Top., Cat., APr.; Porph. Intr.); 4563 (Phy., de An., Sens., Mem., Somn. Vig., Insomn., Diu. Somn., Mot. An., Long., Iuu., Col., Spir., Cael., Gen. Corr., Mete., Metaph., Lin. Ins., Mech., Hist. An.); 4571 (Simp., in Ph. et in de An.); 4574 (Nic. Eth., Mag. Mor., Virt.); 4578 (Oecon., Pol.); 4612 (Poet.); 4616 (Aristot., Probl. et Alex. Aphr., Quaest.); 4627 (Eud. Eth.); 4630 (Mu. et Virt.); 4684 (Rh., de An., Metaph., Virt., Mag.
} 
found in an Aristotelian manuscript (Madrid, BNE, MS 4578) transmitting the text of Economics and Politics. ${ }^{7}$ More relevant to our present purposes, however, is to consider Lascaris' scholarly activities and humanist interests in the Ethics. During his soggiorno in Milan he prepared two beautiful and luxurious exemplars (Madrid, BNE, MS 4574 and Madrid, BNE, MS 4627). These contain, firstly, the texts of Nicomachean Ethics, Magna Moralia, and the pseudo-Aristotelian treatise On Virtues and Vices; and, secondly, in an extremely beautiful handcrafted piece, the text of Eudemian Ethics. Around the same time, he also produced a modest manuscript, probably for individual reading practices (Madrid, BNE, MS 4630); on a few of its folios he copied down the brief apocryphal treatise On Virtues and Vices once more. ${ }^{8}$ As we have already mentioned, despite his long-standing difficult living and working conditions, at a later date he transcribed Economics and Politics in Messina, Sicily. Our research will primarily cover the ethical manuscripts copied during Lascaris' soggiorno in Milan. This essay is intended to describe Lascaris' forms of appropriation of the texts, in a detailed description of the scholarly methods and procedures he executed and implemented whilst reading and preparing his exemplars of the ethical corpus. It will also propose an interpretation of the ideals and morals Lascaris worked from when dealing with Aristotle's ethical works and other texts on virtue.

Our approach is multidisciplinary: on the one hand, our search for reading forms and patterns, scholarly methods, and procedures may be seen as an attempt to deal with, distinguish and highlight the practices of written culture inherited from Antiquity and still carried out by scholars up to the Renaissance. We attempt thus to reconstruct the historical background and reveal the relationship between "the world of the reader" (our scholar) and the world of the text. ${ }^{9}$ However, a history of reading practices is a history of written objects, and in this sense, our evidence for the shaping and recreating of the appropriation of texts is provided by the books themselves: the books that Lascaris copied down and intensively read.

On the other hand, in order to propose an interpretation of our evidence and establish an intellectual framework on which to project both Lascaris' scholarly practices and his humanist activities concerning the ethical Aristotelian treatises,

Mor., Probl.; Simpl., in de An.); 4687 (Aristot., Rh. et Thphr., Char.); Oxford, Bodleian Library, Laud gr. 45 (Porph., Intr.; Aristot., Cat., Int., APr., APo., Top., SE); Paris, BnF, gr. 2028 (de An., Sens.); Vatican, BAV, ottob. gr. 178 (Rh.).

${ }^{7}$ Cf. Martínez Manzano (1997) 191-196; Wilson (2017) 20.

${ }^{8}$ Cf. Andrés (1987) 54-55, 150-151, 157-158.

${ }^{9}$ Cf. Cavallo \& Chartier (2011) 25-27; Chartier (1997) 273. 
we rely on the suggestive approach popularized by Pierre Hadot and summarized in the motto "philosophy as a way of life". According to Hadot, the ancient tradition of historians of philosophy, as represented by Diogenes Laertius, focused on philosophers' biographies and their schools, while a shift of emphasis, already underway during the Middle Ages, placed the point of interest on the doctrines, the theoretic speeches, and the philosophical systems. From the latter perspective, learning philosophy was equal to acquiring a discourse; from the former, however, learning philosophy was equal to acquiring a way of life. ${ }^{10}$ According to Hadot, life and discourse were intrinsically linked to each other in Antiquity. They came together again in personalities like Friedrich Nietzsche or Søren Kierkegaard, and contemporary researchers have been looking for evidence of this idea of "philosophy as a way of life" in prominent figures of the Renaissance, like Francesco Petrarca, Leonardo Bruni, Giovanni Pico della Mirandola, and Erasmus of Rotterdam. ${ }^{\text {II }}$ Lascaris cannot be considered a philosopher, not in accordance with the Western traditional canons. He was, however, someone who worked with philosophical texts in great detail; someone who read them intensively; someone who, to a certain extent, modelled or shaped his practical affairs and his life in accordance with philosophical discourse. Highly important for building our explanatory framework is the notion of spiritual exercises suggested by Hadot. These are also practices, or rather therapies, intended to produce a transformation or modification of the self. Philosophy is conceived, in this sense, as a search for self-

\footnotetext{
${ }^{10}$ Cf. Hadot (2000) 11-15.

${ }^{11}$ Cf. Sellars (2020); Domanski (1996). I am mostly indebted to Sellars' perspectives on
} the continuity and cultivation of the concept of philosophy as a way of life during the Renaissance. However, I do not completely agree with his criticism against Kristeller, in the sense that Kristeller "denied any philosophical status to the humanists". On the one hand, it is without a doubt that Kristeller made a great contribution to the revaluation of the Renaissance philosophy; on the other, he was aware that Humanism was mainly a literary and rhetorical movement, not a philosophical one, so there was no Renaissance philosophy as such or a set of common philosophical ideas shared by all humanists. Instead, there was a common thread of educative, scholarly, and stylistic ideals. He was aware that there were no leading philosophical figures of an unquestionable importance during the Renaissance, and was also willing to admit that in order to correctly understand and assess humanists' contribution to philosophy, we must bear in mind that philosophers from any time might have held scholarly and literary interests and not just scientific and theological ones. Furthermore, Kristeller explicitly highlighted the role that humanists played in enriching the amount of philosophical texts we can currently read and the importance of their scholarly work in granting us direct access to the texts of the main philosophers from Ancient Greece. Cfr. Kristeller (2013) 12-16. 
improvement, as a life of self-cultivation, as a $\tau \dot{\varepsilon} \chi \curlyvee \eta$ of self-modelling, and as a practice intended to bring about the best human being possible.

We aim to project Lascaris' practices and activities on the framework of the motto "philosophy as a way of life". Lascaris' handwritten culture, along with its methods and procedures, will come to light as we carefully consider his books. We define these methods and procedures in terms of reading practices and particular modalities of the use of texts associated with the written culture. However, we also take into account philosophy as a way of life, in terms of 'spiritual exercises' aimed at self-improvement through dealing with philosophical texts. Answering the question about Lascaris' interests on Ethics thus entails digging deeper into his own concept of philosophy, intellectual activity, and scholarly practices. Our purpose is to prove that Lascaris' conception of philosophy was that of "philosophy as way of life", as therapy, as an uninterrupted exercise of thinking and reasoning in search of a better life. Our interpretation will be confirmed when we consider Lascaris' own statements about philosophy in his personal correspondence. Our research is an invitation to consider the role of the idea of "philosophy as a way of life" in the development of Byzantine and Renaissance written culture.

Philosophy as a way of life and handwritten culture

If philosophy is to be understood here as a pursuit for the best life possible and as a commitment to self-improvement, our figure of reference must be Socrates. He encouraged his fellow citizens to lead a life of self-examination; he sought out all those who had any reputation for wisdom or knowledge and raised uncomfortable questions; he discovered again and again that they did not actually know what they thought they did. ${ }^{12}$ Socrates' mission was, as prescribed by the Delphi Oracle, to live the life of a philosopher, to examine himself and others ( $\varphi$ i and others aware of their own ignorance, and, in this sense, of their own lives. ${ }^{13}$ This was a way of life: a life of enquiry and research, which led to a deep change in everyone who was involved and affected. Socrates' fellow citizens were expected to begin asking themselves important questions concerning their own lives, as he already did: Did they really know what they believed they knew? Were they really what they believed to be? By pursuing a life of philosophy himself,

\footnotetext{
${ }^{12}$ Cf. Plat. Apol. 21b-22e.

${ }^{13}$ Cf. Plat. Apol. 28e 5-6.
} 
Socrates called others' lives into question. ${ }^{14} \mathrm{He}$ claimed to take care of men's lives, and men are no more than their souls. ${ }^{15}$ In this sense, taking care of life is a spiritual matter, and this spiritual dimension is of great importance when it comes to dealing with a Renaissance Christian scholar like Lascaris. Even more relevant is that caring for the soul is a prerequisite for being involved in politics. ${ }^{16}$ Furthermore, nothing is more important for Socrates than looking after his own soul. As such, faced with the possibility of escaping from prison and the death penalty by breaking the law, he preferred to obey laws unrestrictedly instead of damaging his soul, regardless of any dire consequence. ${ }^{17}$ By contrast, Socrates was determined not to let anything or anybody to prevent himself from living a life of examination, since in his own view, the greatest good of a man was "to discuss vir-

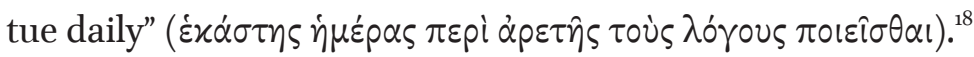

Aristotle's ethical and political concerns and enquiries indeed dealt with the perfect human life, but also the question as to how to rule the city in order to

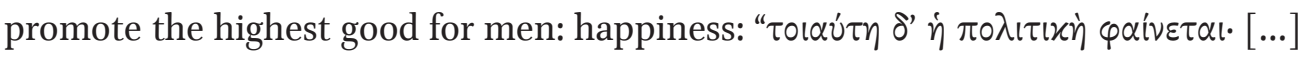

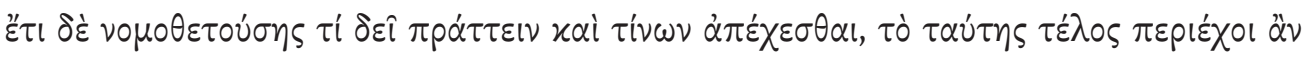

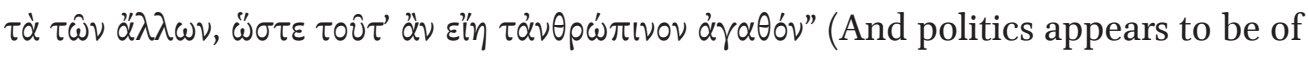
this nature; [...] and since, again, it legislates as to what we are to do and what we are to abstain from, the end of this science must include those of the others, so that this end must be the good for man) ${ }^{19}$ However, in contrast to Socrates, the best way of life for Aristotle was not a life of daily conversation about virtues, but a life of contemplation. For him, ethical virtues were desirable, not for their own sake, but as part of an ultimate goal. For example, either we practise justice in political affairs because we aim for our own happiness or the happiness and wellbeing of others, or we behave courageously in war and military actions because we hope for peace and leisure to enjoy life. Nevertheless, we do not cultivate either for the sake of justice or courage on their own. In the case of contemplation, though, the state of happiness we obtain is perfect, and nothing else comes from contemplation except contemplation itself. ${ }^{20} \mathrm{~A}$ life of contemplation brings man to a higher degree of existence; man participates in the divine, and this activity, according to the most divine element in us (i.e. intellect), is the closest human

\footnotetext{
${ }^{14}$ Cf. Hadot, ¿Qué es la filosofía antigua?, pp. 38, 233.

${ }^{15}$ Cf. Plat. Alc. 1, 13oc 1-3.

${ }^{16}$ Cf. Plat. Alc. 1., 119b-126a.

${ }^{17}$ Cf. Plat. Crito, 48b-d; Gonzalez-Calderon (2008).

${ }^{18}$ Cf. Plat. Apol. 38a 3.

${ }^{19}$ Aristot. Nic. Eth. 1094a 27-1094b 7, tr. by W. D. Ross.

${ }^{20}$ Cf. Aristot. Nic. Eth. 1177 b 4-26.
} 
activity to the divine, and therefore, the happiest activity. ${ }^{21}$ It is because of the contemplation of god ( $\dot{\eta} \tau \circ \hat{v} \theta \varepsilon \circ \hat{v} \theta \varepsilon \omega \rho i \alpha$ ) that we should direct our lives virtuously, and rid ourselves of anything hindering or affecting the exercise of reason. ${ }^{22}$ In this sense, virtue is practised for the sake of wisdom, and a life of contemplation demands a successful ethical and political life. Furthermore, some material conditions are required for the exercise of ethical virtues (but not in the case of intellectual virtues). For the exercise of liberality, for example, a man needs money; otherwise, it is impossible to exercise this ethical virtue. ${ }^{23}$ Ethical virtues require external things, and therefore do not fully depend on us alone; by contrast, the activity that uses the most divine element in our souls falls entirely upon us. Therefore, this exercise is the most perfect activity any man can bring about. Nevertheless, wise men do live in a society and, for this reason, as long as they search for virtue in every aspect of life and they choose to live according to virtue, they also seek to teach others to live accordingly. ${ }^{24}$ Moreover, both for the city

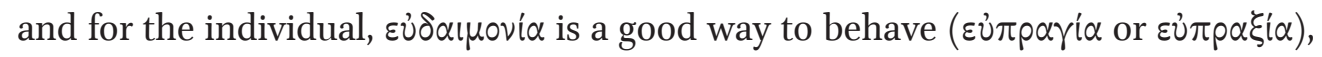
and contemplation (like virtue) is an exercise or a practice in accordance with the most divine element in us. ${ }^{25}$ To summarize, then, those devoted to philosophy were called upon to live, as far as possible, the life of the gods and to exercise contemplation; but to the same degree, they were also responsible for living a virtuous life and making their co-citizens virtuous as well. ${ }^{26}$ Both activities, contemplation and virtue, are performed in accordance to the divine nature within us, and we should recognize a certain continuity between the exercise of virtue in the public sphere and the exercise of contemplation.

Searching for virtue in the public sphere was also a good life according to Aristotle, not the best, but still a life worth living. Living a good life was an activity; hence, we should bear in mind a certain kind of criticism against Plato and Socrates, and accept that the important issue is not to know what virtue is but how we can all become virtuous. ${ }^{27}$ The causes of a good life, virtue, and happiness are indeed actions. Acquiring justice, bravery, prudence, or self-control is a matter of continuous training. A lyre-player becomes a bad or a good player by playing the lyre, and the same is true with arts and abilities, and of course, in the case of vir-

\footnotetext{
${ }^{21}$ Cf. Aristot. Nic. Eth. 1177a 12-18.

${ }^{22}$ Cf. Aristot. Eud. Eth. 1249b 16-23.

${ }^{23}$ Cf. Aristot. Nic. Eth. 1178a 28-29.

${ }^{24}$ Cf. Aristot. Nic. Eth. 1178 b 3-7.

${ }^{25}$ Cfr. Aristot. Pol. 1325 b 14-16.

${ }^{26}$ Cf. Hadot (2000) 103-104.

${ }^{27}$ Cfr. Aristot. Eud. Eth. 1216b 3-25.
} 
tue. ${ }^{28}$ Every philosopher and philosophical school in Antiquity believed that individuals could shape and model their nature in order to learn and cultivate the best way of life. Modelling the characters of human beings is a matter of the utmost importance. According to the first-century Stoic philosopher Musonius Rufus, there are two kinds of spiritual exercises: those suitable for the soul and those common to the body and the soul. Intellectual life is a sort of promotion and cultivation of the inner self, intellectual activities and practices are intended to strengthen the soul and the most refined human capacities. Exercises common to the body and soul, like withstanding cold, heat, thirst, or hunger, avoiding pleasures, or remaining patient under suffering, are intended to make someone unmoved by discomforts and corporal needs, to prepare the body for virtuous action and educate a strong, courageous, and self-restraining soul. ${ }^{29}$ Modelling human life is possible and politicians and legislators were, according to Aristotle, the craftsmen of good or bad citizens: men able to perform noble and virtuous actions, or the opposite. ${ }^{30}$ Professors, teachers, and coaches have also always been responsible for modelling human beings. Men like Lascaris, who was responsible for teaching reading and grammar, classical literature, and of course, philosophy, fulfil a civic mission in that they educate young people and nurture their spiritual and intellectual capacities and abilities.

Reading practices can be seen as common spiritual exercises intended to strengthen both the body and the soul. Lascaris, a scholar educated in Constantinople under the tuition of John Argyropoulos, inherited an everlasting tradition of reading practices performed by only a few people, but a few of great importance: men of letters who were for centuries at the pinnacle of cultural life in Byzantium, and were largely responsible for the preservation and study of ancient Greek texts. ${ }^{31}$ It is true that writing was mainly an activity intended to provide sustenance and earn money, even in the case of monks living a life of renunciation within cloisters. ${ }^{32}$ Moreover, Roman, or rather, early Byzantine rulers eagerly looked for bureaucrats with an education in classical literature. Indeed, an ordinance issued by Constantius and Julian in 360 established a list of requirements to be fulfilled by candidates applying to work in the top ranks of civil service: "No person shall obtain a post of the first rank unless it shall be proved that he excels in long practice of liberal studies, and that he is so polished in liter-

\footnotetext{
${ }^{28}$ Cfr. Aristot. Nic. Eth. 1103a 31-1103b 25.

${ }^{29}$ Cf. Lutz (1947) 54; Hadot (2000) 207-208.

${ }^{30}$ Cfr. Aristot. Nic. Eth. 1099b 29-32.

${ }^{31}$ Cfr. Cavallo (2017) 236-238.

${ }^{32}$ Cfr. Cavallo (2O17) 216.
} 
ary matters that words flow from his pen faultlessly". ${ }^{33}$ Nevertheless, aside from the pursuit of both money and well-educated bureaucrats, there was also a spiritual dimension to writing practices. In fact, they might be more precisely named

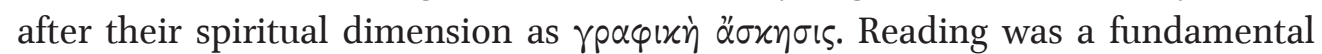
ability for monks, acquired either before entering religious life or within the walls of the monastic institutions..$^{34}$ The reading and the writing of religious texts was aimed at "building and fortifying" the soul and the texts most widely read in Byzantium were therefore those best suited to devotional practices. ${ }^{35} \mathrm{~A}$ set of repetitive and focused procedures was implemented for devotional reading. Selected passages from the Holy Scriptures were time and time again read and heard, eventually learned by heart, and whispered regularly in the course of daily activities. The ultimate goal was no other than "to internalize the word of the Lord, and to fortify the spirit against demons and temptations" ${ }^{36}$ In addition, copying manuscripts is a particularly demanding and difficult activity. Hence, Byzantine scribes designated their writing exercise as $\pi$ óvoৎ in its dual sense: a work and a suffering. They even consecrated their handwriting activity to God. ${ }^{37}$ To summarize, manufacturing sacred books as a whole was seen as a devotional practice. Moreover, these devotional practices can be considered as embodying a dimension of the ascetic type of reading, but there are two other modes of reading also belonging to this dimension. The first of these was an intensive reading that was carried out by top Byzantine scholars. At the intersection between reading and writing, it was present in a variety of forms, such as adding notes, comments, glosses, and scholia, paraphrasing, excerpting, and transcribing. ${ }^{38}$ Furthermore, this intensive reading enabled anyone involved in the process of textual appropriation to carefully and deeply meditate about its meaning, while using his own hand to comment and annotate it. The second kind of reading belonging to this dimension is exemplified by the groups of literates in Byzantium interested mainly in Classical texts who worked together to produce handwritten books as an intellect-forming activity. These groups of scholars, which acted simultaneously

\footnotetext{
${ }^{33}$ Theodosian Code, 14.1.1. This passage is quoted and translated by Wilson (1996) 2.

${ }^{34}$ Cfr. Cavallo (2017) 193.

${ }^{35}$ Cfr. Cavallo (2017) 232-233.

${ }^{36}$ Cfr. Cavallo (2017) 195-196.

${ }^{37}$ Cfr. Muzerelle (2013) 160; Cavallo (2017) 207. An interesting colophon is found in the Aristotelian manuscript Neapolitanus III $D$ 37, written by Isaac Argyros, who, after finishing, completed his Organon manuscript in folio $285 \mathrm{r}$ with the metrically arranged

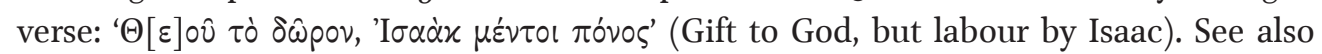
Bianconi (2008) 359-36o; Gonzalez-Calderon (2014) 292-297.

${ }^{38}$ Cfr. Cavallo (2017) 25-26.
} 
as writing circles ("circoli di scrittura"), became quite popular during the Palaeologan revival; nonetheless, they were already present in Constantinople long before. In terms of their composition and goals, they can be depicted as communities of cultivated people gathered around an important figure of the intellectual world, preparing, under his tuition, books aimed at satisfying higher cultural interests. ${ }^{39}$ From their formative activities, we possess stunning and valuable manuscripts written down by a number of hands all towards a single common goal. Details on just three of these manuscripts are provided in what follows:

1) Four hands copied our oldest version of Poetics and Rhetoric, Paris, BnF, gr. 1741, working at various different times, each using different exemplars, and splitting their responsibilities and the amount of text to be written down unequally.

2) Three hands worked on the preparation of the monumental codex Paris, BnF, gr. 1853 transmitting in its most ancient quires, along with Physics and Metaphysics, a collection of the minor Aristotelian writings on physics, psychology, and biology (among them, Cael., Gen. Corr., Mete., de An., Sens., Mot. An.). A number of Aristotelian textual witnesses was reproduced in this collection, whilst other indirect sources were copied down on the margins in order to support the interpretation of Aristotle's writings. The whole production process was controlled, corrected, and supplemented by the leader of this writing circle.

3) A greater number of hands were responsible for the transcription of another monumental manuscript (Firenze, Biblioteca Medicea Laurenziana, Laur. Plut. 85.1): a reference encyclopaedia of the most renowned ancient and medieval Greek Aristotelian commentators, produced in Constantinople by a group of people whose "practices of study" included the transcription of Aristotelian commentaries and further exegetical materials. ${ }^{40}$ This manuscript was not prepared during the first Byzantine revival, as both Paris manuscripts were, but during the second revival: the well-known Palaeologan Renaissance.

What we are keen to emphasize here is that the collaborative writing activities of the Byzantine circoli di scrittura were performed as study practices, and in this sense, they sought for the cultivation of a specific type of human being as someone eager to carry out physical endeavours by copying down a book, and qualified enough to deeply comprehend and appreciate the excellences of the written

\footnotetext{
${ }^{39}$ Cfr. Cavallo (2004) 646.

${ }^{40}$ Cfr. Cavallo (2004) 647-651.
} 
text. To borrow an example from Musonius Rufus, careful meditation about what is good, what is only apparently good, what is bad, and what is only apparently bad could be successfully carried out by anyone involved in the production of an exemplar of the Aristotelian ethical writings. ${ }^{41}$

\section{Lascaris' humanist activities concerning the Aristotelian Ethics}

Lascaris did not always live in as uncomfortable conditions as he did in the years he spent in Messina. His most productive period was in Milan (1458-1465), where he enjoyed particularly agreeable facilities for scholarly practices under the patronage of Duke Francesco Sforza. ${ }^{42}$ These conditions are reflected in the manuscripts he produced at that time. His exemplars of the Nicomachean and the Eudemian Ethics date back to his fruitful stay in Milan.

The manuscript Madrid, BNE, MS 4574 is clear evidence of the most refined cultural practices in book production. He made prodigal use of the supplies of fine paper available to him, writing a few lines per page in a steady, angular, skilful, accurate but still informal script, setting an uncrowded lay-out with wide blank spaces aimed either at providing helpful reading aids, or to house beautifully illuminated capital letters (that are not always completed) at the heading of each book of the Nicomachean Ethics (see Plate 3). There are no gold decorations (as in the case of Lascaris' Eudemian Ethics exemplar), but it is still a beautifully handcrafted instrument of teaching and learning. For the main text, he used a sepia brown ink, and for the headings and other uses, a reddish-purple one. The title of each book and the letters at the beginning of each chapter are rubricated, and a note in the margin indicates the corresponding chapter ( $\kappa \varepsilon \varphi \dot{\alpha} \lambda \alpha \iota 0 v)$ number (see Plates 1 and 3). Numerous content clarifications were also added using a purple-coloured ink. Some of these are merely intended to describe the content of relevant passages: for instance, at the beginning of the second book of $\mathrm{Ni}$ comachean Ethics (folio 12 recto), where Aristotle states the difference between intellectual and moral virtue, Lascaris describes the issues dealt in the passage by

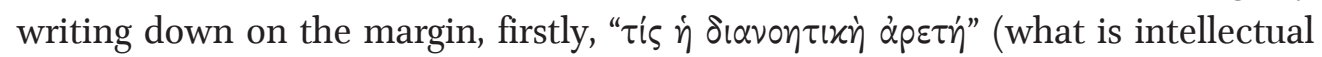

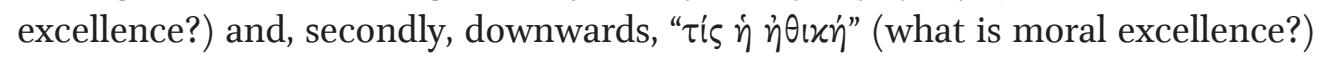
(see Plate 3). On the same folio, Lascaris incidentally summarizes the argument

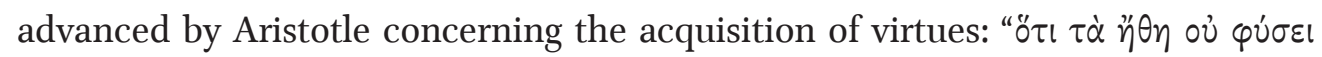

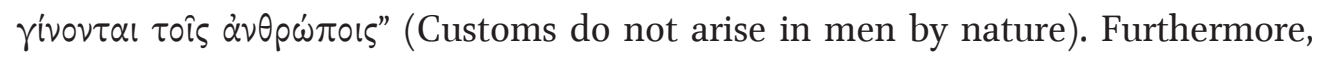
Lascaris pays special attention to the references and quotations offered by the

\footnotetext{
${ }^{41}$ Cf. Lutz (1947) 54,

${ }^{42}$ Cfr. Fernández Pomar (1966) 218-219; Martínez Manzano (1998) 9-2o.
} 
Stagyrite. Thus, on folio 3 recto (see Plate 1 ), next to the passage $1095 \mathrm{~b} 10-13$ where Aristotle quotes four verses borrowed from Hesiod's Works and Days, he adds the

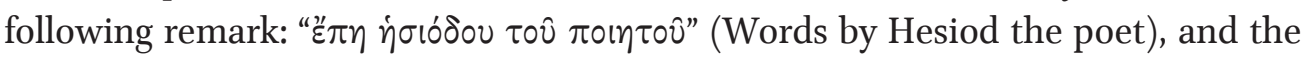
same sort of identifying clarification is to be found on folios 20 verso and 33 verso, where Aristotle refers to Euripides and Simonides, respectively. Content descriptions, summarized arguments, and chapter headings might be seen as "editorial devices" aimed at helping readers to find specific issues discussed in the Ethics. ${ }^{43}$ His explanatory remarks concerning authors and literary works reveal the interest of a humanist scholar, who took great delight in classical literature and had acquired an encyclopaedic knowledge about it.

Lascaris performed refined humanist philological operations on the texts he read. After writing down his Nicomachean Ethics, he probably collated his copy both with the same exemplar already used for the transcription and also with a different version available to him. There are many minor corrections set above the line written with the same sepia brown ink used for the main text. During a later revision of his work, he might have noticed mistakes made during the copying; simple mistakes that were easy to detect and to amend. As a result, he would have then proceeded to correct them. Some of these minor mistakes and corrections are here listed:

\begin{tabular}{|c|c|c|}
\hline & Menda & Emendationes Lascarianae \\
\hline $1102 a 16$ & $\tau \hat{\omega} \nu$ & $\tau \circ \hat{}$ \\
\hline $1102 a 20$ & $\tau \iota \mu l \omega \tau \varepsilon \dot{\rho} \rho \nu$ & $\tau \iota \mu \iota \omega \tau \varepsilon \dot{\varepsilon} \rho \alpha$ \\
\hline $1110 a 23$ & $\varphi \alpha u ́ \lambda \circ \nu$ & $\varphi \alpha u ́ \lambda \circ v$ \\
\hline 1110a 30 & 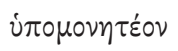 & 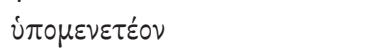 \\
\hline $111 \mathrm{Ob}_{5}$ & $\dot{\alpha} x \circ v \sigma i \alpha$ & $\varepsilon x \circ v^{\prime} \sigma \mid \alpha$ \\
\hline
\end{tabular}

He would have noticed his own omissions and then restored the text using the same sepia brown ink, not above the line but on the outer margin. We can see this on folio 4 recto, where, after setting a caret under the line to signal the miss-

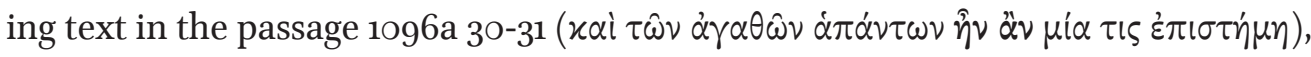
he supplemented on the margin $\varepsilon$ in $\ddot{\alpha} \nu$, which is not the authentic reading according to our reference edition by Bywater, but is still admissible (see Plate 2). It seems likely that Lascaris might not have added these words without the assistance of a second exemplar. A group of annotations confirms that he would have conducted a comparison with another manuscript. Some of these alternative readings were written down above the line as well, not in the sepia brown ink but in the red purple one used for headings, summaries, and other content explana-

\footnotetext{
${ }^{43}$ Cfr. Cavallo (2011) 125-126.
} 
tions. One of these readings can be found on folio 1 recto, at the very beginning of

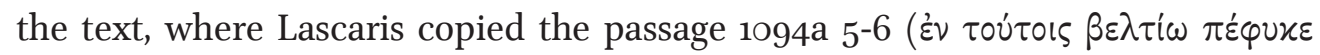

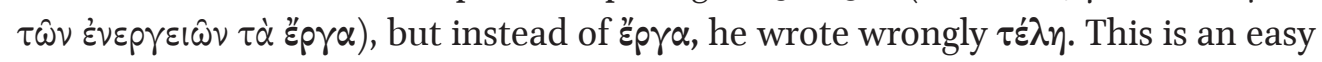
mistake to make in the context, but, by any account, it is a corruption. Another reading of the same kind is added on folio 4 recto, where, although the passage

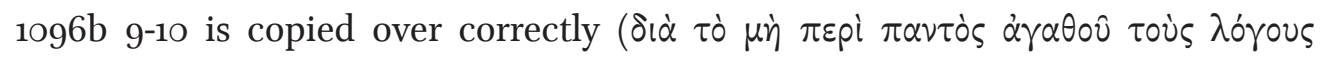

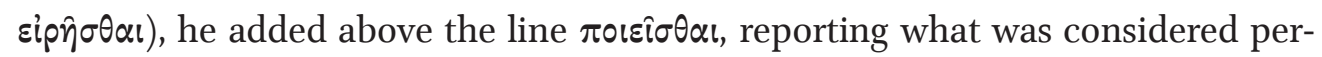
haps an admissible reading preserved by the tradition at the time. Both readings are preceded by a simple $\hat{\eta}$, and, in fact, many more alternative readings were signalled on the inner margins using the same particle and also in red purple ink. Two more examples are worth taking into account. Firstly, Lascaris copied down

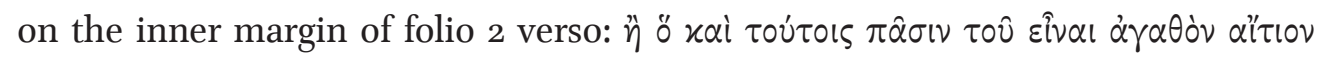

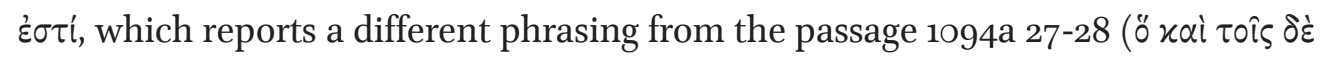

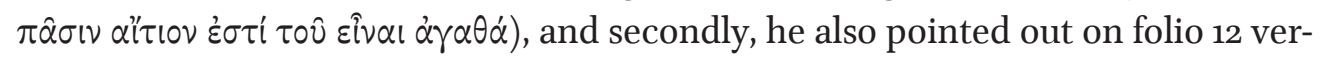

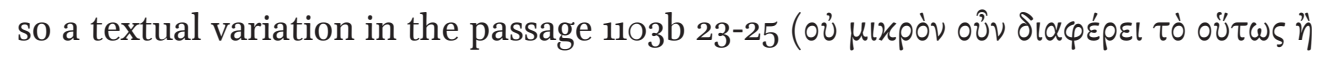

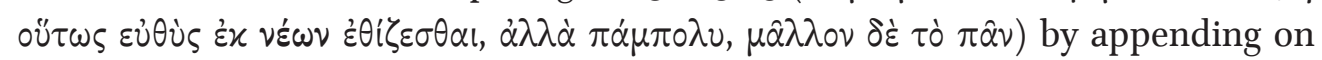

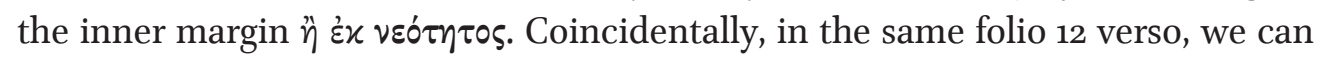
also find evidence that he compared his work against another manuscript. In the

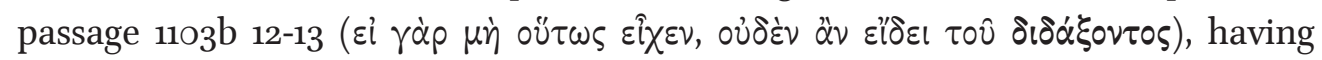
written down $\delta เ \delta \dot{\alpha} \sigma \kappa \varepsilon \sigma \theta \alpha \iota$ instead of $\delta เ \delta \dot{\alpha} \xi \circ v \tau \circ \varsigma$, Lascaris includes the correct reading on the inner margin with red purple ink, preceded by $\gamma \rho \alpha \dot{\varphi} \varphi \tau \alpha \iota$ abbreviation ( $\gamma$ p.), a symbol used in Byzantine manuscripts to point out variant readings (see Plate 4). The same is the case on folio 53 recto, where he annotated in the margin the correct reading $\lambda \circ \gamma i \zeta \varepsilon \tau \alpha$ l preceded by the already-mentioned $\gamma \rho$. to

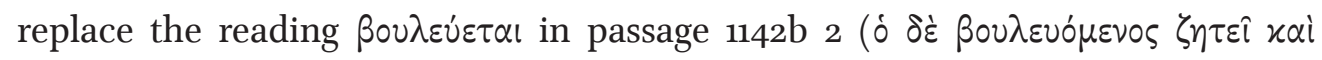
$\beta$ and most likely emended due to comparison with a different textual witness.

Which exemplar did Lascaris use to transcribe the text? Which one did he use to correct it? We are still basing our study on the transmission of the Nicomachean Ethics, and more research is still needed to disentangle some complex knots and threads in the Renaissance manuscript tradition. However, a few readings compiled by Bywater in his edition point towards an apparently close filiation between Madrid, BNE, MS 4574, Venice, Biblioteca Nazionale Marciana, gr. 213, and Paris, BnF, gr. 1854. More specifically, five readings present in the former manuscript can be also read in the latter two:

\begin{tabular}{|c|c|c|}
\hline $1195 \mathrm{~b} 4$ & 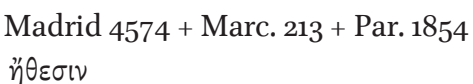 & $\begin{array}{l}\text { Cett. } \\
\varepsilon \theta \varepsilon \varepsilon \sigma \downarrow\end{array}$ \\
\hline $1102 b_{3}$ & $\alpha \nu \theta \rho \omega \pi \iota x \dot{~}$ & $\dot{\alpha} \nu \theta \rho \omega \pi i \nu \eta$ \\
\hline
\end{tabular}




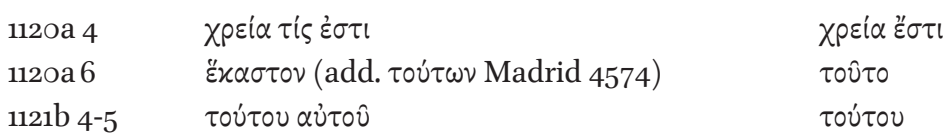

Furthermore, a correction found above the line on folio 3 recto suggests that Lascaris was using either Marcianus, Parisinus, or a closely related manuscript, whilst reading it a second time, correcting minor mistakes, and recording some

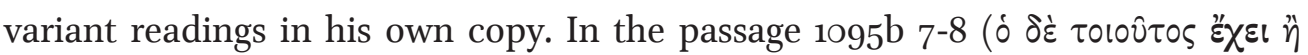

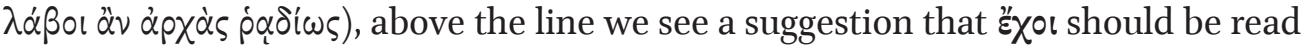
instead of $\varepsilon^{\prime} \chi \varepsilon \varepsilon$. This can be considered an easy correction in the context, and one that might be carried out without necessarily consulting a second exemplar. However, $\tilde{E}^{\prime} \times 0 \mathrm{l}$ is once again preceded by $\grave{\eta}$, and therefore we are allowed to assume that Lascaris found the reading in a different text, writing it down in his own copy afterwards. According to Bywater's apparatus criticus, the very same reading is present in Parisinus 1854, and a "deformation" of this reading ( $\eta$ है $\chi 01$ ) is also to be read in Marcianus 213 (see Plate 1): ${ }^{44}$

$$
\begin{aligned}
& \text { Madrid 4574 + Marc. } 213 \text { + Par. } 1854 \text { Cett. }
\end{aligned}
$$

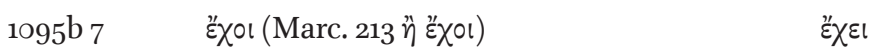

It is worth bearing in mind that Marcianus 213 belonged to Cardinal Bessarion. Lascaris and Bessarion wrote letters to each other, and by studying their epistolary exchange we can identify a scholarly relationship aimed at the cultivation of philological activities concerning Ancient Greek and Byzantine texts and at the sharing of books required to promote such activities. ${ }^{45}$ Indeed, we know for certain that Lascaris used one of Cardinal Bessarion's manuscripts (Venice, Biblioteca Nazionale Marciana, gr. 214) to transcribe his exemplar of Aristotle's Metaphysics (Madrid, BNE, MS 4563$).{ }^{46}$ In this context, it comes as no surprise to learn that Lascaris had access to Bessarion's own copy of Nicomachean Ethics, either as a basis for his transcription or for his emendatio. In a way, Bessarion and Lascaris were both members and supporters of highly educated scholarly circles in Italy, which included Byzantine immigrants and Italian humanists, all serving a common cultural project.

\footnotetext{
${ }^{44}$ Bywater's report of the reading in Venice, Biblioteca Nazionale Marciana, gr. 213 is likely a mistake due to the misunderstanding of the function of particle $\ddot{\eta}$, which introduces readings present in textual witnesses other than the one used as basis for the copying.

${ }^{45}$ Cfr. Martínez Manzano (1998) 177.

${ }^{46}$ Cfr. Harlfinger (1979) 24; Martínez Manzano (1998) 15 .
} 
Lascaris' exemplar of Eudemian Ethics is today preserved in the manuscript Madrid, BNE, MS 4627. This manuscript reflects the same highly refined practices in book production already observed in Madrid 4574. What is more, the most striking feature in Madrid 4627 is that all illuminated capital letters have been fully completed; they have even been decorated from Book one to Book five with gold ink (see Plates 5 and 6). This is further evidence of the ideal working conditions that Lascaris enjoyed during his time in Milan. It also serves as an example of why these two manuscripts are deemed luxurious. In addition to their elaborate appearance, however, they were also carefully composed instruments of knowledge. Lascaris used the manuscript held in Florence, Biblioteca Medicea Laurenziana Laur. Plut. 81.20 as a model for transcribing his Eudemian Ethics, which at the time belonged to the humanist and bibliophile Francesco Filelfo (1398-1481). ${ }^{47}$ In this undertaking, Lascaris also made it easier for the reader to consult and compare specific passages by adding content descriptions, summaries, and even rubrics at the beginning of each section. Likewise, he noted the names of the ancient authors mentioned or quoted by Aristotle in the margins and used quotations marks to signal passages borrowed from literary texts. He probably found some passages of special interest and highlighted them through the accustomed $\sigma \eta \mu \varepsilon i \omega \sigma \alpha l$ and $\omega \rho \alpha$ abbreviations. For instance, he threw the passage 1222b 15-18 into stark relief (see Plate 7), a key passage for understanding Aristotle's argument about seeing a human being as principle of moral action: 'Elఠi

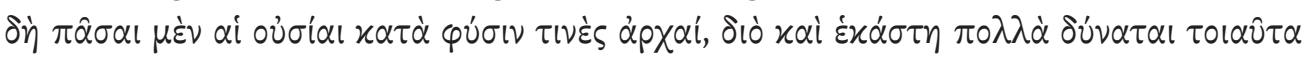

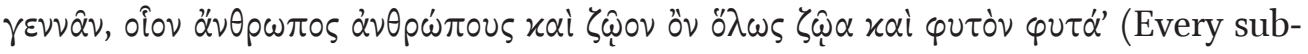
stance is by nature a sort of principle; therefore each can produce many similar to itself, as man man, animals in general animals, and plants plants). ${ }^{48}$

One interesting question to consider is what Lascaris' main purpose may have been when he produced these luxurious versions of the Aristotelian ethics. Both manuscripts belonged to Lascaris' personal library and he may well have produced these two beautiful pieces simply because he wanted them for himself. He was probably very proud of his handicraft, but his original purpose might have been something else. As we have already mentioned, in Byzantium manuscripts were mainly produced in order to sell them and cover basic living costs. ${ }^{49}$ With this in mind, we could also infer that Lascaris' original purpose was to earn some money from the sale of these beautiful books. In Milan, he had many students who were close relatives to powerful and wealthy people, and he might have easi-

\footnotetext{
${ }^{47}$ Cfr. Harlfinger (1979) 29o; Martínez Manzano (1998) 10-11.

${ }^{48} \mathrm{Tr}$. by J. Solomon.

${ }^{49}$ Cfr. Cavallo (2017) 216.
} 
ly found clients for his books. It is perhaps easier to explain the striking material features of these beautiful pieces if we assume they were products for trade and not personal reference. Lascaris may have not found any appropriate customers while he was still living in Milan and may have simply decided to keep them for himself. Nevertheless, it seems clear that he had a keen interest in the moral education of his apprentices. The books he produced were not only stunning and worthwhile components of any personal library; they were also instruments for the acquisition of moral knowledge and the provision of a civic education for young people.

The last item we will examine is the Madrid, BNE, MS 4630. Although this was also produced during Lascaris' stay in Milan in 1464, as indicated on folio 78 verso, Madrid 4630 is a relatively different manuscript to Madrid 4574 and 4627 . It is not as luxurious, even though some material features are remarkable. It was made with the same high quality paper used for Madrid 4574, as evidenced by the watermarks on both manuscripts. ${ }^{50}$ There are also blank spaces reserved for illuminated capital letters, which were not always drawn, and the use of coloured ink responds to the same conventions as in Madrid 4574 and 4627. However, Madrid 4630 is a small in-octavo book aimed at satisfying personal requirements and interests, rather than an exemplar likely produced to earn some money. At any rate, this manuscript is a carefully handcrafted instrument of knowledge: Lascaris annotated the margins and added brief content summaries. He rubricated the initial letters in each section, corrected minor mistakes made during the copying, and reported variants found in other textual witnesses. On folio 47 verso, for instance, we see, firstly, three content descriptions written on the outer margin with red

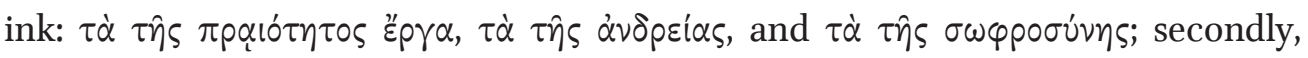
three initial rubricated letters corresponding to three paragraphs dealing with even temper, courage, and self-control, respectively. Thirdly, he corrects xeivors for vixns twice, firstly in the main text and a second time in the inner margin. He also adds the missing gival in the main text through a caret, which is written down on the outer margin with the same sepia brown ink used for the transcription. Other additions include the possible variant $\alpha \delta \varepsilon$ si $\alpha \nu$ preceded by $\eta$ and corresponding to $\dot{\alpha} \delta \circ \xi \dot{\xi} \alpha \nu$ in the main text, and his numbering above the line of the consequences of possessing self-control (see Plate 8). It is perhaps even more interesting to note that Madrid 4630 is an assemblage of assorted texts, not all of which are philosophical; however, three are concerned directly with the theme of

\footnotetext{
${ }^{50}$ The same watermark belonging to the family 'Emblem' is visible on the conjoint leaves $78 / 79$ and 77/80 of Madrid 4630, as well as on the bifolium 2/5 of Madrid 4574. Cfr. Andrés (1987) 54-55, 157-158.
} 
virtue. Along with the already-mentioned pseudo-Aristotelian treatise On Virtues and Vices, the manuscript also includes an anonymous treatise On Virtue and Georgius Gemistus Plethon's short essay On Virtues. For our purpose of characterizing Lascaris' working methods on texts, we will leave aside the latter by Plethon, and will pay special attention to the former two. ${ }^{5}$

It is plainly evident that the pseudo-Aristotelian On Virtues and Vices was of particular interest for Lascaris, and this interest is reflected in his manuscripts. Lascaris owned three manuscripts containing such a treatise. As we have already pointed out, in addition to Madrid 463o, Madrid 4574 was also a version of $\mathrm{On}$ Virtues and Vices written by Lascaris himself. There was another copy of the same treatise in his own books, which though contained the Magna Moralia as well: Madrid, BNE, MS 4684. This manuscript was written, for the most part, by an unknown $14^{\text {th }}$ century copyist and belonged beforehand to Georgius Gennadius Scholarius and Theodorus Gaza. It contained a wide collection of Aristotelian texts, and probably had a part to play in the diffusion of Aristotelianism during the Renaissance..$^{52}$ In any case, the antigraph of Madrid 4574 concerning the apocryphal treatise On Virtues and Vices is Madrid 4684. They share a number of textual features inherited from an hyparchetype that is no longer preserved and which gave rise to a family (designated as $\psi$ ) of roughly twenty manuscripts in circulation throughout Italy from the beginning of the $15^{\text {th }}$ century onwards. The most striking feature is a reordering of passage 125ob 43-1251a 1, which is also

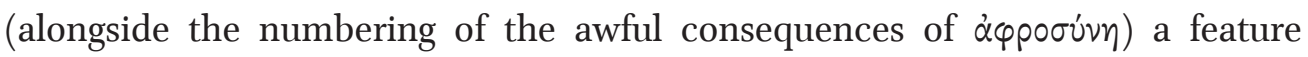
found in all manuscripts of the same family, but absent in the remaining manuscript tradition, and so we do not consider it to be authentic:

\begin{tabular}{|c|c|}
\hline \multicolumn{2}{|c|}{ Ps.-Arist. $V V, 125 \mathrm{ob} 43^{-1251 \mathrm{a}} 1$} \\
\hline Family $\Psi$ & Textus receptus (ed. Hutchinson) \\
\hline 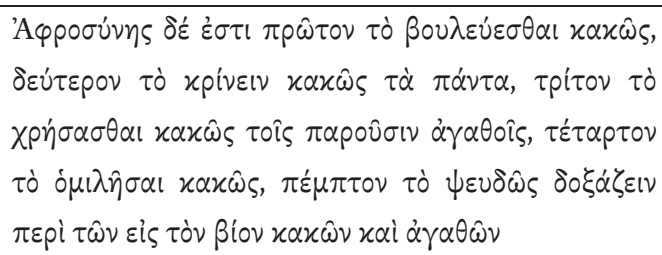 & 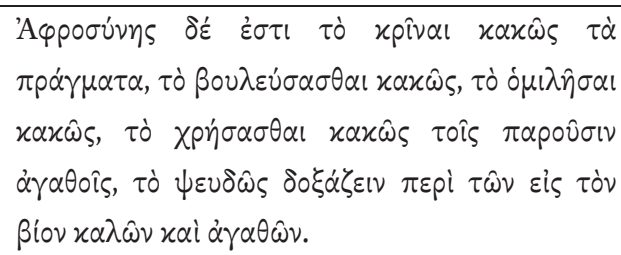 \\
\hline
\end{tabular}

It is worth emphasizing that the numbering of the consequences of virtues and vices covers the whole text, and belongs exclusively to the family we call $\psi$.

\footnotetext{
${ }^{51}$ For Plethon's treatise On virtues, see Tambrun-Krasker (1987).

${ }^{52}$ Cfr. Eleuteri (2016) 8o-81.
} 
Lascaris transcribed his model very carefully, including all these numerical sequences. Despite this clear interpolation, both manuscripts preserve a goodquality text, and only one conjunctive error between Madrid 4574 and 4684 separates them from the remaining tradition:

$\begin{array}{lll} & \text { Madrid } 4574+\text { Madrid } 4684 & \text { Cett. } \\ 125 \text { ob } 8 & \dot{\alpha} \pi 0 \lambda \alpha v \sigma \tau i x \hat{\varsigma} \varsigma & \dot{\alpha} \pi 0 \lambda \alpha v_{\sigma \varepsilon \omega \varsigma}\end{array}$

What is even more remarkable is that Lascaris made only one minor mistake during his copying: he omitted an article present in his model in line $125 \mathrm{ob} 42$. This is the only piece of evidence we have that Madrid 4574 is independent from Madrid 4684.

In the case of Madrid 4630, the situation is much more complicated. Apart from preparing his exemplar through intensive reading, it is clear that Lascaris collated different versions of the texts in order to produce an improved new recension. He even apparently rephrased the wording to some extent in accordance with his own stylistic preferences and his own comprehension of the ethical doctrines therein exposed. The fact that he collated at least two different manuscripts can be confirmed by the report of variants in the margins of the manuscript, as already mentioned, but also, by the manner in which he dealt with passage 125ob 43-1251a 1, which is, as we said, reordered in $\psi$ :

Ps.-Arist. $V V$, 125 ob 43-1251a 1

\begin{tabular}{|c|c|}
\hline $\begin{array}{l}\text { Recensio Lascariana } \\
\text { Madrid 463o, f. } 49 \mathrm{r}\end{array}$ & Family $\Psi$ \\
\hline 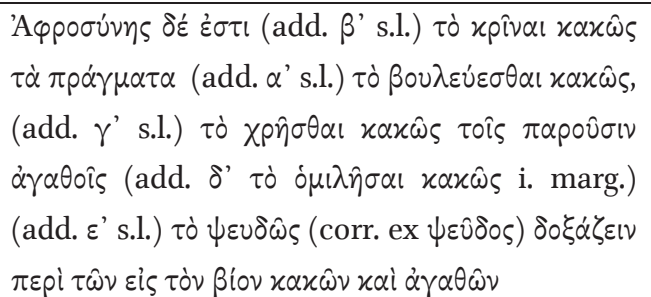 & 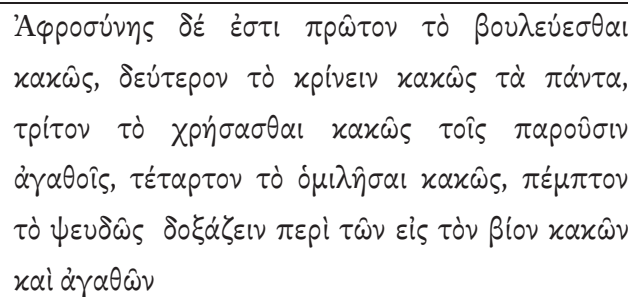 \\
\hline
\end{tabular}

It is clear that Lascaris copied down the passage in the canonical order of the most authorized branches of the tradition. In a posterior revision, however, he reordered the text in accordance with the order characteristic of $\psi$. He even corrected a minor omission in the margin of folio 49 recto - a brief omission of one of the consequences of $\alpha \varphi p o \sigma u ́ v \eta$, preceded by the corresponding number in $\psi$. Afterwards, he reordered the passage using a different ink and added in all cases the numbering of items (see Plate 9). Lascaris undoubtedly made use of a manuscript belonging to family $\psi$ while he was revising his own copy, but it is still interesting 
for us to identify which exemplar was initially used for the transcription. It could not be a manuscript from the family $\psi$. There are indeed some readings that can be seen as Lascaris' own stylistic innovations in that they are not, as far as we know, transmitted by any branch or single manuscript from the direct tradition:

\begin{tabular}{|c|c|c|}
\hline & Madrid 4630 & Cett. \\
\hline $\begin{array}{l}1250 \mathrm{~d} 4 \\
125 \text { oa } 13\end{array}$ & $\pi \rho \dot{s}$ & हiऽ \\
\hline 125 oa 15 & $\delta \nu \sigma \tau u x i \alpha \nu$ (Stob.) & $\dot{\alpha} \tau u x_{i}^{\prime} \alpha \nu$ \\
\hline
\end{tabular}

However, there are some other intriguing readings that can be traced back to Moskva, Gosudarstvennyj Istoričeskij Musej, Syn. gr. 231:

\begin{tabular}{|c|c|c|}
\hline $125 \mathrm{Oa} 32$ & $\begin{array}{l}\text { Madrid } 4630+\text { Moskva Syn. gr. } 231 \\
\psi \varepsilon \kappa \tau \dot{\alpha}\end{array}$ & $\begin{array}{l}\text { Cett. } \\
\varphi \varepsilon u x \tau \dot{\alpha}\end{array}$ \\
\hline $51 \mathrm{a}$ & $\pi$ pòs & $\pi \varepsilon p i$ primum \\
\hline ib & $\delta \nu \sigma \tau u \chi i \alpha \nu$ & $\dot{\alpha} \tau u x^{i} \alpha \nu$ \\
\hline
\end{tabular}

Interestingly, Moskva Syn. gr. 231 is somehow isolated in the tradition of the On Virtues and Vices, and according to recent research, this manuscript had no subsequent descendants. This means that, at this point, we are unable to establish whether Lascaris could access a textual witness bearing these readings or not, and if so, which it was. They might indeed be seen as innovations, but in such a case, it seems a very rare coincidence.

The examination of the anonymous On Virtues in Madrid 4630 reveals a clearer rephrasing of the text. This anonymous On Virtues follows two different routes of transmission, which also represent two different redactions or forms of the text. Firstly, it is appended as conclusive piece in the most part of Joseph Rhacendytes' De virtute manuscript tradition. It is also interesting to note that this piece is interchanged in a number of textual witnesses of Rhacendytes' De virtute with the pseudo-Aristotelian On Virtues and Vices. Secondly, the anonymous On Virtues is transmitted independently with a different redaction in two other manuscripts besides Madrid, BNE, MS 463o: Venezia, Biblioteca Nazionale Marciana, gr. IV.43 and Wien, Österreichische Nationalbibliothek, phil. gr. 192. The text has been already edited, along with the whole De virtute by Rhacendytes. However, the independently transmitted version is currently being revised and has not yet been published. ${ }^{53}$ The three manuscripts transmitting the latter date back to the second half of the $14^{\text {th }}$ century and the beginning of the $15^{\text {th }}$, so that they are, in any case, posterior to Rha-

\footnotetext{
${ }^{53}$ Cfr. Gielen (2016) LXXIV-LXXXII.
} 
cendytes' lifetime, since he died around $1330 .{ }^{54}$ It is plausible that they represent a rework of the original, either Rhacendytes' De virtute or a common source used by both Rhacendytes himself and an anonymous author, whose text was also accessible during Lascaris' lifetime. It could be that Lascaris was responsible for rephrasing Rhacendytes' De virtute, but Lascaris did not claim or acknowledge authorship for

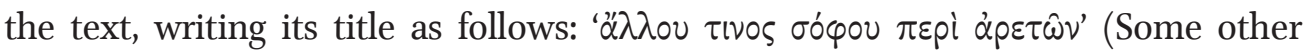
wiseman's On Virtues). In addition, we are not at this point able to confirm whether Marcianus gr. IV.33 and Vindobonensis philosophicus gr. 192 derive from Madrid 4630 or not. At any rate, we can be sure that the text was deliberately reframed. A quick comparison between both texts allows us promptly to note some simplifications, rearrangements, and stylistic adjustments. Significant differences are evident from the outset:

\begin{tabular}{|c|c|}
\hline $\begin{array}{c}\text { J. Rhacendytae, De virtute, }[\mathrm{P}] 851^{-862} \\
\text { [ed. E. Gielen] }\end{array}$ & $\begin{array}{l}\text { Anonymi, De virtute, } \\
\text { Madrid BNE 463o, f. 51v }\end{array}$ \\
\hline 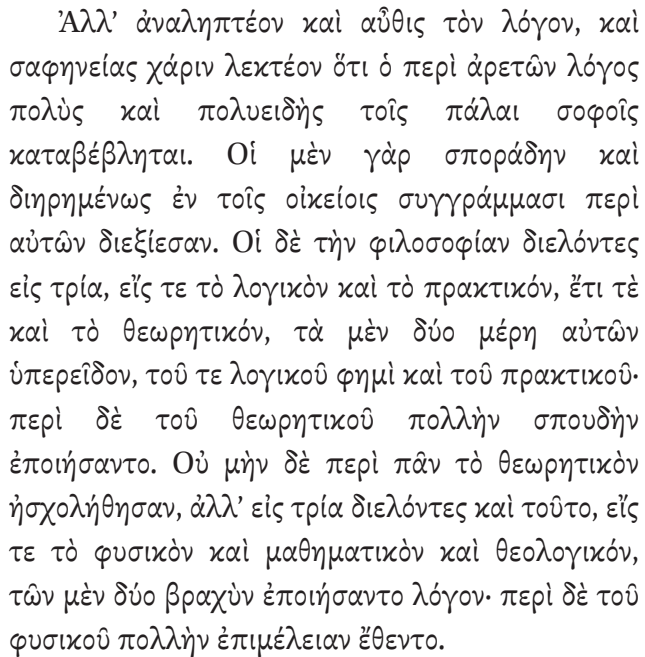 & 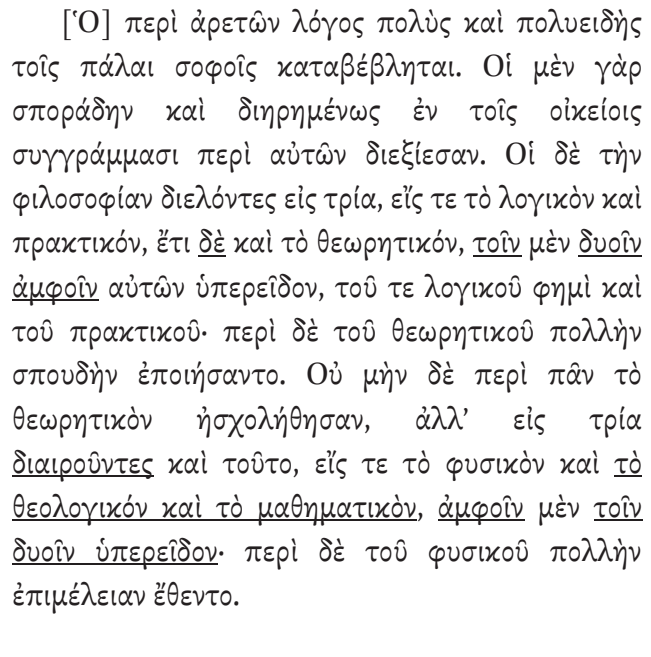 \\
\hline
\end{tabular}

As we have already noted, the pseudo-Aristotelian On Virtues and Vices and the anonymous On Virtues were interchanged at the end of Rhacendytes' De virtute. The reason for this is that both treatises are actually comprehensive catalogues of virtues and vices. The exact number and classification of virtues and vices differ substantially in both texts. The anonymous On Virtues lists altogether

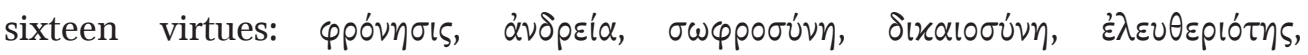

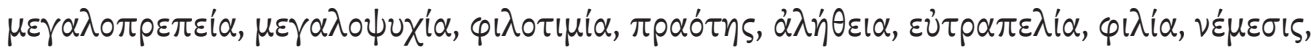

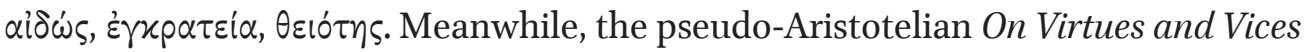

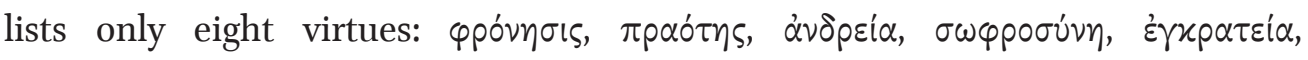

\footnotetext{
${ }^{54}$ Cfr. Hunger (1961) 301-303; Mioni (1972) 231-232.
} 


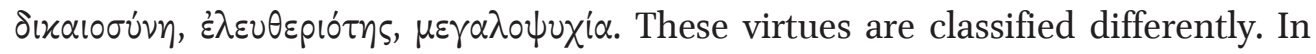
the pseudo-Aristotelian On Virtues an Vices, the order in which they are listed is

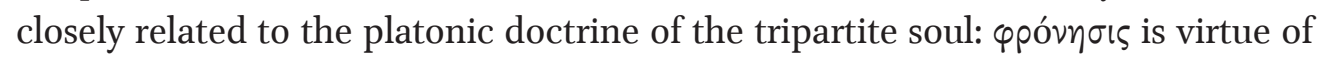
the rational soul, $\pi \rho \alpha$ ó $\eta \varsigma$ and $\alpha \nu \delta \rho \varepsilon i \alpha$ are virtues of the irascible soul, $\sigma \omega \varphi p \circ \sigma \nu \dot{v \eta}$

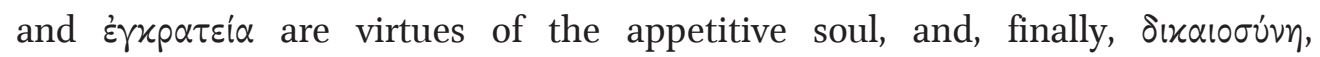

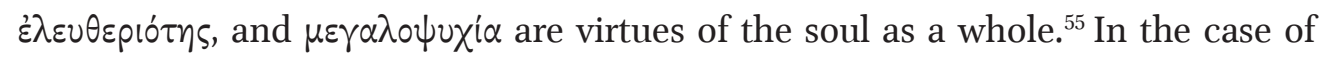
the anonymous On Virtue, the situation is a bit more complicated. The first four virtues match the four cardinal virtues of the ancient world inherited by Christianity: prudence, courage, temperance, and justice. The remaining virtues branch

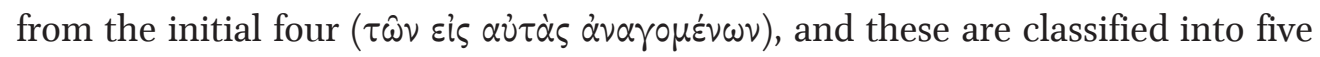
groups: ${ }^{56}$ firstly, those referring to the use and consideration of material goods

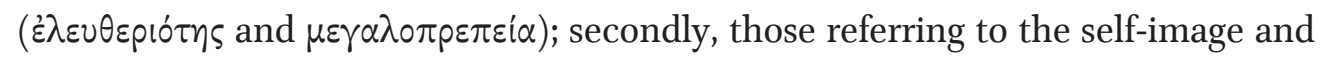
self-estimation $\left(\mu \varepsilon \gamma \alpha \lambda \circ \psi v \chi^{i} \alpha\right.$ and $\left.\varphi i \lambda \circ \tau \mu \mu_{i} \alpha\right)$; thirdly, those referring to communi-

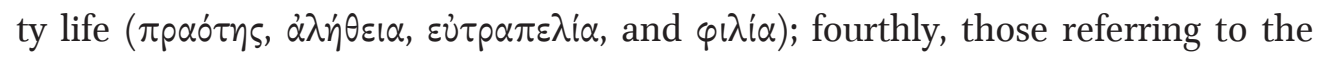
management of passions, pleasures, and sufferings ( $\nu \varepsilon \dot{\mu} \mu \sigma \tau \varsigma, \alpha i \delta \omega^{\prime} \varsigma$, and $\dot{\varepsilon} \gamma \kappa \rho \alpha \tau \varepsilon \dot{\alpha} \alpha$ ); and fifthly, referring to one's relationship with God ( $\theta \varepsilon$ เó $\eta \varsigma)$. Likewise, the number of vices in the anonymous On Virtue is much greater than in the pseudoAristotelian On Virtues and Vices. The reason for this is that, while in the latter treatise every vice matches a unique virtue, in the former, two different vices are opposed to a single virtue: one that surpasses it by excess and one that does not reach it by default. Hence, while in the pseudo-Aristotelian On Virtues and Vices a single vice, $\delta \varepsilon i \lambda i \alpha$ (cowardice), is opposed to $\alpha v \delta \rho \varepsilon i \alpha$ (courage), in the case of the

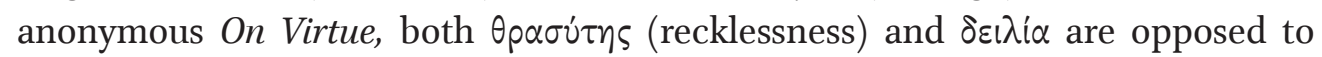

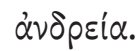

All in all, it is worth considering why Lascaris was interested in both treatises. The answer is most likely that they could serve as practical guides for exercising virtues. They were actually handbooks that taught how to behave correctly, and not just theoretic treatises aimed exclusively at giving an intellectual comprehension of the subject. In this sense, there is one mention in the anonymous On Virtue to Socrates that is of particular interest. In the opening paragraph we have already quoted, before starting to list the different virtues and vices, the anonymous author refers to the ancient philosophers who dealt with ethical concerns somehow. Socrates is mentioned as the first intellectual figure to explore moral

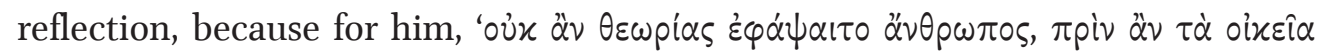

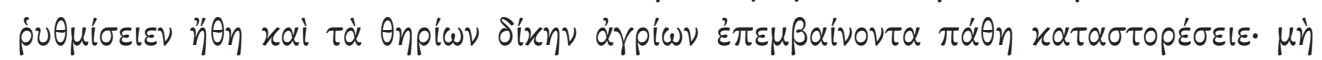

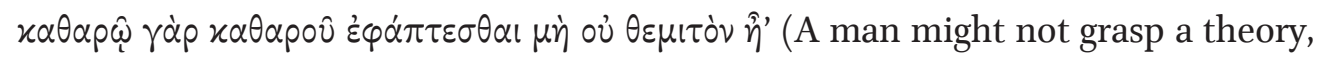

\footnotetext{
${ }^{55}$ Cfr. Ps.-Arist. $V V, 1249$ a 31-1249b 29, ed. Hutchinson.

${ }^{56}$ Cfr. J. Rhacendytae, De virtute [P], 929-93o, ed. Gielen.
} 
before he has adapted his own customs, and has calmed the passions threatening him in the manner of the wild beasts, for something impure may not grasp something pure).$^{57}$ This quotation shows, then, that our anonymous author saw moral education as a precondition for anybody wishing to take any steps forward in philosophy. Both the anonymous author and Lascaris were of the opinion that those educated and trained in this tradition would have thought the same.

\section{Lascaris' ethical way of life}

We have so far tried to illustrate and describe the way in which Lascaris tackled Aristotelian ethical writings, based on the way in which they are depicted in his own books. Our next task is to reveal his philosophical background in order to analyse Lascaris' scholarly practices.

To begin with, let us start with his circles in Milan. Lascaris was officially appointed Greek professor in 1463 with the support of forty-seven personalities in the city, among them, Pier Candido Decembrio (1399-1477). Pier Candido enjoyed a successful political and diplomatic career as did his father, Uberto (1350-1427). Both men served powerful leaders and were also humanists. Uberto was a close friend to Michael Chrysoloras and exchanged letters with Leonardo Bruni and other important figures in society. ${ }^{58} \mathrm{He}$ and Chrysoloras even translated Plato's Republic into Latin. Pier Candido collected his father's scattered writings and one of these is of particular interest for us: Uberto's De re publica. This work is preserved in manuscript Milan, Biblioteca Ambrosiana, B 123 sup. In it, Uberto exposes his political theory and explicitly explores the moral duties of citizens:

We should also devote ourselves with special love to our country where our parents, children, wives, relatives, and friends dwell. [...] Moreover, every citizen should take care to live with his fellow citizens with a sense of right that is fair and equal; he should neither behave himself in a servile and abject manner, so that he is held in contempt, nor should he get above himself so that he appears to oppress others. [....] Finally, he should so conduct himself that he be reputed a good man and a fairminded [aequus] citizen by everyone. Let him be a cultivator of the virtues, especially justice and moderation. ${ }^{59}$

For Uberto Decembrio every citizen was responsible for common good and scholars should also, of course, look after the welfare of the community. In this

\footnotetext{
${ }^{57}$ Cfr. J. Rhacendytae, De virtute [P], 872-875, ed. Gielen.

${ }^{58}$ For Uberto and Pier Candido Decembrio's biographies, see Dizionario biografico degli italiani (1960-2013), searching for 'Decèmbrio, Uberto' and 'Decèmbrio, Pier Candido'.

${ }^{59}$ This passage is quoted and translated by Hankins (1995) 329 .
} 
sense, he was a champion of what is known as civic humanism: just like other intellectual figures, he held important civil positions, but he also promoted and undertook scholarly practices, which were a key element of humanist cultural and political activity. ${ }^{60}$ To summarize, he was a public man, concerned about the moral improvement of his co-citizens. Thus, Decembrio's understanding of humanist scholarly practices is also an important element to consider when examining the context of Lascaris' work on Aristotle's ethical corpus.

We have now seen the situation in Milan, but it is also worth considering Lascaris' own statements about philosophy and scholarly practices in general. These statements can be read in Lascaris' correspondence with some of his contemporary humanists. There are fifteen letters written at different points in Lascaris' lifetime, stylistically reworked at a later stage, and currently collected in a single volume (Madrid, BNE, MS 4620). ${ }^{61}$ Lascaris' epistles are beautiful pieces of rhetoric, reflecting his vast knowledge of Greek literature and his deep stylistic sensibility. He strongly encourages his addressees to lead a life of scholarly and intellectual work, and explicitly praises such a life. He was acquainted enough with Aristotle's philosophy to incorporate some elements of the Aristotelian ethical doctrine in his exhortative and laudatory letters. An example of this can be found in a letter addressed to a certain John, who may have been the same man who translated Lascaris' Epitome octo partium orationis into Latin for the first time.

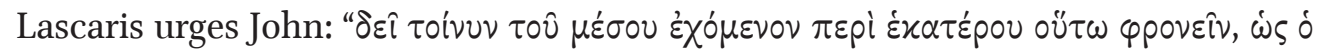

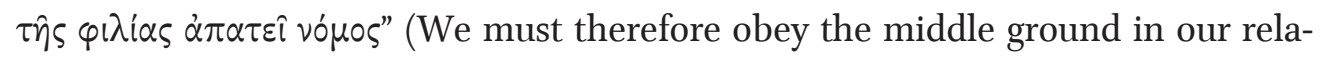
tionships and behave prudently, as is required by the law of friendship). ${ }^{62}$ Friendship was an important aspect of Aristotle's ethical doctrine: joining others in the search for a common goal was at the root of every society, and friendship is a key element of a happy life both for individuals and for communities. A perfect friendship is only possible between individuals who are noble and equal in virtue, however, and true friends give and receive the same reciprocally; otherwise, they are not really friends. ${ }^{63}$ Lascaris advises his addressee to practise an absolute mildness $(\pi \rho \alpha o ́ \tau \eta \tau \alpha \pi \alpha \nu \tau \eta \lambda \hat{\eta})$ towards others, in accordance with the monastic life. He urges him to put the affairs of others before his own, but not those of Lascaris himself, since ethical life prescribes something different for him: namely,

\footnotetext{
${ }^{60}$ For the intellectual movement described as civic humanism, see Baron (1955); Hankins (1995).

${ }^{61}$ Some drafts are also preserved in a different manuscript: Madrid, BNE, MS 4636. For Lascaris' epistolography, see Martínez Manzano (1998) 165-177.

${ }^{62}$ C. Lascaris, Epistolae quatuordecim familiares, col. 959 b-c, ed. Migne.

${ }^{63}$ Cfr. Aristot. Nic. Eth. 1156 b 7-8; 1158 b 1-3.
} 
the search for the middle term in friendship. These are core elements of Aristotle's ethics that are present in Lascaris' epistolary exchange, but it is even more striking to observe how he praises a philosophical way of life and disdains a life of unproductive leisure and immoral behaviour.

In a touching epistle addressed to the Spanish poet and philosopher, Juan Pardo, who was his disciple in Naples, he expresses his grief because of his own precarious living and working conditions. He also laments the plight and unfortunate fate that some of his most brilliant fellow countrymen faced in Italy. ${ }^{64}$ At the end of the letter, Lascaris bids farewell to his correspondent, demanding bitterly that he should not wait for him. He then goes on to describe his own death, not as an evil, but as an escape from suffering. Likewise, Lascaris praises Pardo not only for having the opportunity to cultivate poetry, but also, because, instead

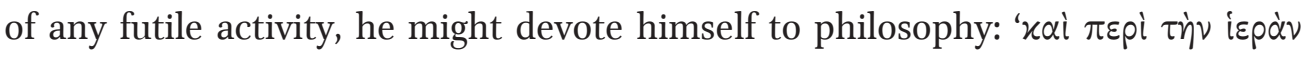

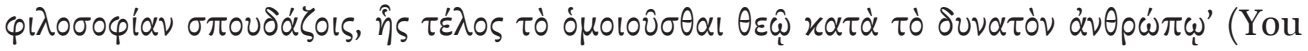
might devote yourself to divine philosophy, whose goal is to make oneself as similar to God as a man can).$^{6}$ The $\delta \mu o i \omega \sigma \iota \varsigma \theta \varepsilon \hat{\omega}$ is a process beautifully described in Plato's Timaeus consisting in regulating our own disordered revolutions of the soul according to the completely stable revolutions of the cosmos, and hence, of the god who created it. ${ }^{66}$ This was without doubt common knowledge for anyone with a typical knowledge of ancient philosophy, but it is in any case a fundamental idea for the conception of philosophy as a way of life. Through the exercise of philosophy, we get closer and closer to our final goal and become more divine than human. In another way, by exercising the divine element in us, we all become similar to the divine. Nevertheless, as we have already pointed out, a philosophical life was, according to Aristotle, not only a life of contemplation, but also a life of cultivating virtues, and Plato tells us in the Theaetetus that this kind of assimilation to God is achieved by becoming lawful and pious with the assistance

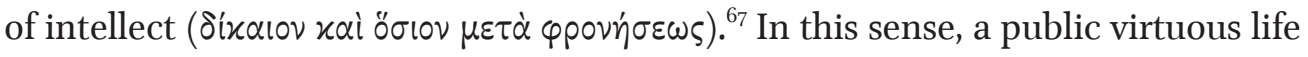
was also a life of assimilation to God.

Lascaris severely reproaches one of his old students, Carolus (a name that was popular among his other disciples) in one of his letters. Lascaris refers to him in an exchange addressed to Andreas di Cremona, a member of Milan Chancellery, ${ }^{68}$ calling him 'The forgetful'. Indeed, in a first letter addressed to Carolus, Lascaris

\footnotetext{
${ }^{64}$ Cfr. Martínez Manzano (1998) 14.

${ }^{65}$ C. Lascaris, Epistolae quatuordecim familiares, col. 958 b-c, ed. Migne.

${ }^{66}$ Cfr. Plat. Tim. 46e 7- 47c 4.

${ }^{67}$ Cfr. Plat. Theaet. $176 \mathrm{~b} 2-3$.

${ }^{68}$ Cfr. Martínez Manzano (1998) 172.
} 
expressed his displeasure at Carolus for his lack of respect towards both his

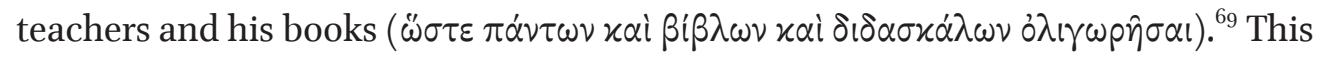
is an important statement for our purposes, because here there is an explicit connection between books and handwritten culture, on the one side, and the spiritual dimension of teaching and learning, on the other. Carolus was rude: he even did not say farewell to Lascaris when he knew that he had to leave. He had borrowed a book from his teacher and had not yet given it him back. To make matters even worse, he was no longer interested in what was for his own good, and focused on his entertainment and pleasure. This is explained in Lascaris' second letter to Carolus. We read that he was seduced by debauchery and gluttony; he no longer nourished his soul, but ate excessively. As the prison of the soul, as his body grew fatter, he weakened his soul. There can be no doubt that he lacked temperance, or rather, self-control. A man who appreciates and remembers what he has learned is supposed to behave otherwise, and such a man is also a man of books. His respect towards books rests somehow on his moral behaviour and his moral behaviour predetermines his esteem of books. More importantly, Carolus' way of life did no good for him, his professor, his fellow mates or the community. To summarize, book culture was a part of moral education, and moral education was simply for the common good.

Happily, not all of Lascaris' disciples were as neglectful as Carolus. One of his most brilliant students was Giorgio Valla (d. 1500), who became a professor who enjoyed great success in Pavia, Genoa, and Venice, and translated a number of scientific and philosophical texts. ${ }^{70}$ Lascaris' and Valla's hands even alternate in a manuscript they copied together: a version of Hippocrates' Aphorismi and Prognosticon (Madrid, BNE, MS 4634). Lascaris wrote a few folios at the beginning of the book and his disciple completed the task. ${ }^{71}$ It was clearly a training activity guided by the teacher and mainly carried out by the student. In his letter, Lascaris glorifies and exalts the excellences of philosophy. He praises Valla for devoting

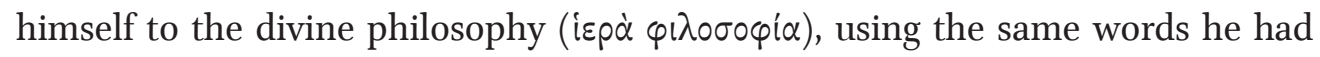
already used to exhort Juan Pardo to live accordingly. Lascaris reminded Valla that philosophy, whose goal was to become as similar to God as possible, was considered by ancient men the art of arts and the science of sciences. In this sense, this discipline was the basis of every art, science, or field of knowledge. Philosophy was therefore a broad-reaching discipline, as Plato himself, according to

\footnotetext{
${ }^{69}$ C. Lascaris, Epistolae quatuordecim familiares, col. 959 d, ed. Migne.

${ }^{70}$ For Giorgio Valla's biography, see Dizionario biografico degli italiani, sub voce.

${ }^{71}$ Cfr. Martínez Manzano (1998) 22-25.
} 


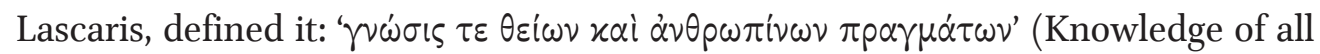
divine and human things). ${ }^{72}$

Giorgio Valla was not the only praiseworthy man of letters to whom Lascaris sent a letter. He also wrote a beautiful eulogy addressed to the Byzantine humanist Theodorus Gaza. The soothsayer Sibyl did not announce Gaza's arrival to Italy, a fortunate land that benefited enormously from his guidance and studies. Happy were those who could take advantage of his talents; miserable were those who harvested the fruits in the past, but now leave them aside. Gaza was someone who clearly understood what was for the common good and Lascaris simply asked him to complete what he had already undertaken for common benefit (zis

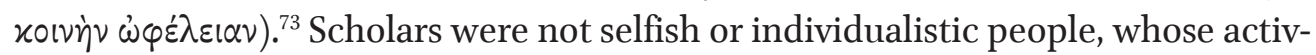
ities were pursued exclusively for the sake of their own interests and benefits. They looked, as politicians and legislators did, for the common good. They were very often teachers, and hence, operated as craftsmen, modelling other men's souls and lives. One of their main tasks was precisely to educate noble and virtuous men, who were expected to behave impeccably, unless their own character spoilt any attempt to improve their moral condition. Lascaris' bitter lament concerning his own unfortunate fate and his fellow countrymen's reveals what he thought was the cause of misfortune: ignorance of letters and philosophy. Rulers were no longer interested in dealing with Homer, Demosthenes, or Plato. They became vicious and were certainly comfortable being so. But their actions affected not only their own lives, but also those of others, for they were responsible for modelling their fellow citizens' spirits and making them either virtuous or vicious. Disregarding philosophy leads to decadence of spirit and the depraved behaviour both of individuals and of the community as a whole. However, disregarding philosophy did not just mean forgetting discourse, but rather refraining oneself from any activity conducting to self-improvement. It was precisely this kind of scholarly practice that Lascaris and his circle of intellectuals aimed to encourage.

\section{Conclusions}

The purpose of this paper was, firstly, to describe and analyse Lascaris' scholarly practices and, secondly, to reveal a philosophical background and an explanatory framework against which to project such practices. Through the examination of his books, we have seen that Lascaris clearly had a deep interest in Aristotle. We have praised his beautifully handcrafted and luxurious exemplars of the Aristote-

\footnotetext{
${ }^{72}$ C. Lascaris, Epistolae quatuordecim familiares, col. 96o b, ed. Migne.

${ }^{73}$ C. Lascaris, Epistolae quatuordecim familiares, col. 961 a, ed. Migne.
} 
lian ethical corpus, but also his scholarly methods and the procedures he applied to turn his books into excellent instruments of knowledge. We have seen that he was especially interested in catalogues of virtues as suitable guides for moral action, and he had access to a text explicitly stating that moral improvement was a prerequisite for proceeding on the path of philosophy. We have also seen that Lascaris developed his intellectual activities in a context of humanists willing to serve their cities both through civil service and scholarship. He explicitly establishes a link between book culture and virtue, in terms of a reciprocal dependence, and he reproaches moral deviation both in the case of his own disciples and of political leaders. Scholarship was, for Lascaris, a service intended for the promotion of the common good. He praised philosophy and especially those men who had devoted themselves to living a life of books, of knowledge, of selfimprovement, and of service to the community. Scholars, as legislators, were responsible for modelling men's lives and, in this sense, scholars were also civic humanists. More research is still needed in order to establish an accurate connection between book culture and moral education. I hope that this study might represent an opening chapter in this line of research.

\section{REFERENCES}

\section{Manuscripts}

Firenze, Biblioteca Medicea Laurenziana, Laur. Plut. 81.20

Firenze, Biblioteca Medicea Laurenziana, Laur. Plut. 85.1

Madrid, Biblioteca Nacional de España (BNE), MS 4549

Madrid, Biblioteca Nacional de España (BNE), MS 4553

Madrid, Biblioteca Nacional de España (BNE), MS 4563

Madrid, Biblioteca Nacional de España (BNE), MS 4571

Madrid, Biblioteca Nacional de España (BNE), MS 4574

Madrid, Biblioteca Nacional de España (BNE), MS 4578

Madrid, Biblioteca Nacional de España (BNE), MS 4612

Madrid, Biblioteca Nacional de España (BNE), MS 4616

Madrid, Biblioteca Nacional de España (BNE), MS 4620

Madrid, Biblioteca Nacional de España (BNE), MS 4627

Madrid, Biblioteca Nacional de España (BNE), MS 4630

Madrid, Biblioteca Nacional de España (BNE), MS 4634

Madrid, Biblioteca Nacional de España (BNE), MS 4636

Madrid, Biblioteca Nacional de España (BNE), MS 4684

Madrid, Biblioteca Nacional de España (BNE), MS 4687

Milan, Biblioteca Ambrosiana, B 123 sup.

Moskva, Gosudarstvennyj Istoričeskij Musej, Synod.gr. 231 
Napoli, Biblioteca nazionale Vittorio Emanuele III, III D 37

Oxford, Bodleian Library, Laud gr. 45

Paris, Bibliothèque nationale de France (BnF), gr. 1741

Paris, Bibliothèque nationale de France (BnF), gr. 1853

Paris, Bibliothèque nationale de France (BnF), gr. 2028

Vaticano, Bibliotheca Apostolica Vaticana (BAV), ottob. gr. 178

Venezia, Biblioteca Nazionale Marciana, gr. 213

Venezia, Biblioteca Nazionale Marciana, gr. 214

Venezia, Biblioteca Nazionale Marciana, gr. IV.43

Wien, Österreichische Nationalbibliothek, phil. gr. 192.

\section{Primary sources}

Barnes, J. ed. (1991) The Complete Works of Aristotle. Bollingen Series LXXI 2. Princeton: Princeton University Press.

Burnet, J. ed. (1900-1902) Platonis Opera, t. I-IV. Oxford: Clarendon Press.

Bywater, I. ed. (1894) Aristotelis Ethica Nicomachea. Oxford: Clarendon Press.

Gielen, E. ed. (2016) Nicephori Blemmydae De virtute et ascesi. Josephi Racendytae De virtute. Corpus Christianorum: series graeca 8o. Turnhout: Brepols.

Hutchinson, D. S. ed. (1998) Pseudo-Aristotle. A Peripatetic Handbook of Virtues and Vices, (unpublished draft edition). Toronto: University of Toronto.

Migne, J.-P. ed. (1866) Constantini Lascaris Epistolae quatuordecim familiares. Patrologiae Cursus Completus: series graeca, CLXI. Paris: Garnier, cols. 957a-964b.

Tambrun-Krasker, B. ed. (1987) George Gémiste Pléthon. Traité des vertus. Corpus Philosophorum Medii Aevii - Philosophi Bizantini 3. Athens: The Academy of Athens - Leiden-New York-København-Köln: Brill.

\section{Secondary literature}

Baron, H. (1955) The Crisis of the Early Italian Renaissance. Civic Humanism and Republican Liberty in an Age of Classicism and Tyranny, vol. 1. Princeton: Princeton University Press.

Bianconi, D. (2008) "La controversia palamitica. Figure, libri, testi e mani," Segno e Testo, $6,337-376$.

Cavallo, G. (2004) "Sodalizi eruditi e pratiche di scrittura a Bisanzio," in: J. Hamesse, ed. Bilan et perspectives des études médiévales (1993-1998). Euroconférence (Barcelone, 8-12 juin 1999). Actes du IIe Congrès Européen d'Études Médiévales. Turnhout: Brepols, 645-665.

Cavallo, G. (2011) "Entre el volumen y el codex. La lectura en el mundo romano," in: G. Cavallo \& R. Chartier, eds. Historia de la lectura en el mundo occidental. Madrid: Taurus, 99-128.

Cavallo, G. (2017) Leer en Bizancio, tr. by Antonio Natolo. Colección Scripta Manent. Buenos Aires: Ampersand. 
Cavallo, G. \& Chartier, R. (2011) Historia de la lectura en el mundo occidental, tr. by M. Barberán \& M. P. Palomero. Pensamiento. Madrid: Taurus.

Chartier, R. (1997) "Du livre au lire," Sociologie de la communication, 1(1), 271-29o.

Andrés, G. de (1987) Católogo de los códices griegos de la Biblioteca Nacional. Madrid: Ministerio de Cultura, Dirección General del Libro y Bibliotecas.

Dizionario biografico degli italiani (196o-2013). Roma: Istituto della Enciclopedia Italiana Fondata da Giovanni Treccani. http://www.treccani.it/biografico [accessed 29 February 2020]

Domanski, J. (1996) La philosophie, théorie ou manière de vivre: Les controversies de l'Antiquité à la Renaissance. Fribourg: Cerf-Editions Universitaires de Fribourg.

Eleuteri, P. (2016) "I manoscritti dell'opera pseudo-aristotelica De virtute," Scripta: An International Journal of Codicology and Palaeography, 9, 73-88.

Fernández Pomar, J. M. (1966) "La colección de Uceda y los manuscritos griegos de Constantino Láscaris," Emérita 34(2), 211-288 + 9 plates.

Gonzalez-Calderon, J. F. (2008) "Hacer lo que la ciudad ordene. ¿Se puede estar obligado por la ley a cometer injusticia?” in: G. von der Walde \& J. Rojas, eds. IV Jornadas Filológicas. Aproximaciones interdisciplinarias a la Antigüedad griega y latina. Bogotá: Universidad de los Andes-Universidad Nacional de Colombia, 173-183.

Gonzalez-Calderon, J. F. (2014) Historia de la tradición textual del comentario de Alejandro de Afrodisias a los Tópicos de Aristóteles (unpublished doctoral thesis). Getafe: Unversidad Carlos III de Madrid.

Hadot, P. (2000) ¿Qué es la filosofía antigua?, tr. by E. Cazenave Tapie Isoard. Sección de Obras de Filosofía. México: Fondo de Cultura Económica.

Hankins, J. (1995) "The "Baron Thesis" after Forty Years and some Recent Studies of Leonardo Bruni," Journal of the History of Ideas, 56(2), 309-338.

Harlfinger, D. (1971) Die Textgeschichte der pseudo-aristotelischen Schrift Пвpi àtó $\mu \omega \nu$

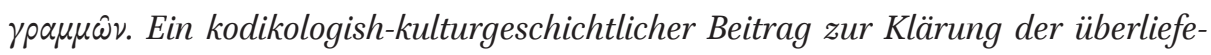
rungsverhältnisse im Corpus Aristotelicum. Amsterdam: Adolf M. Hakkert.

Harlfinger, D. (1979) "Zur Überlieferungsgechichte der Metaphysik," in: P Aubenque, ed. Études sur la Métaphysique d'Aristote. Actes du VIe Symposium Aristotelicum. Paris: Vrin, 7-36.

Hunger, H. (1961) Katalog der Griechischen Handschriften der Österreichischen Nationalbibliothek, Teil ı, Codices historici, codices philosophici et philologici. Wien: Georg Prachner.

Kristeller, P. O. (2013) Ocho filósofos del Renacimiento italiano, tr. by M. Martínez Peñaloza. Breviarios, 210. México: Fondo de Cultura Económica.

Lutz, C. E. (1947) "Musonis Rufus, the Roman Socrates," Yale Classical Studies, 10, 3-147.

Martínez Manzano, T. (1998) Constantino Láscaris: Semblanza de un humanista bizantino. Nueva Roma 7. Madrid: Consejo Superior de Investigaciones Científicas.

Mioni, E. (1972) Bibliothecae Divi Marci Venetiarum, Codices Graeci Manuscripti, Vol. I, Codices in classes a prima usque ad quintam inclusi, Pars altera. Roma: Istituto Poligrafico dello Stato. 
Muzerelle, D. (2013) "Colophons et souscriptions. Mentions de date, d'origine ou de copiste," in: P. Gehin, ed. Lire le manuscript medieval. Paris: Armand Colin, 157-181.

Sellars, J. (2020) "Renaissance Humanism and Philosophy as a Way of Life," Metaphilosophy, 51(2-3), 226-243.

Timperley, Ch. H. (1839) A Dictionary of Printers and Printing, with the Progress of Literature, Ancient and Modern. London: H. Johnson.

Wilson, N. (1996) Scholars of Byzantium. repr. London-Cambridge, Mass.: Gerald Duckworth-The Medieval Academy of America.

Wilson, N. (2017) From Byzantium to Italy: Greek Studies in the Italian Renaissance. repr. London-New York: Bloomsbury.

Plates

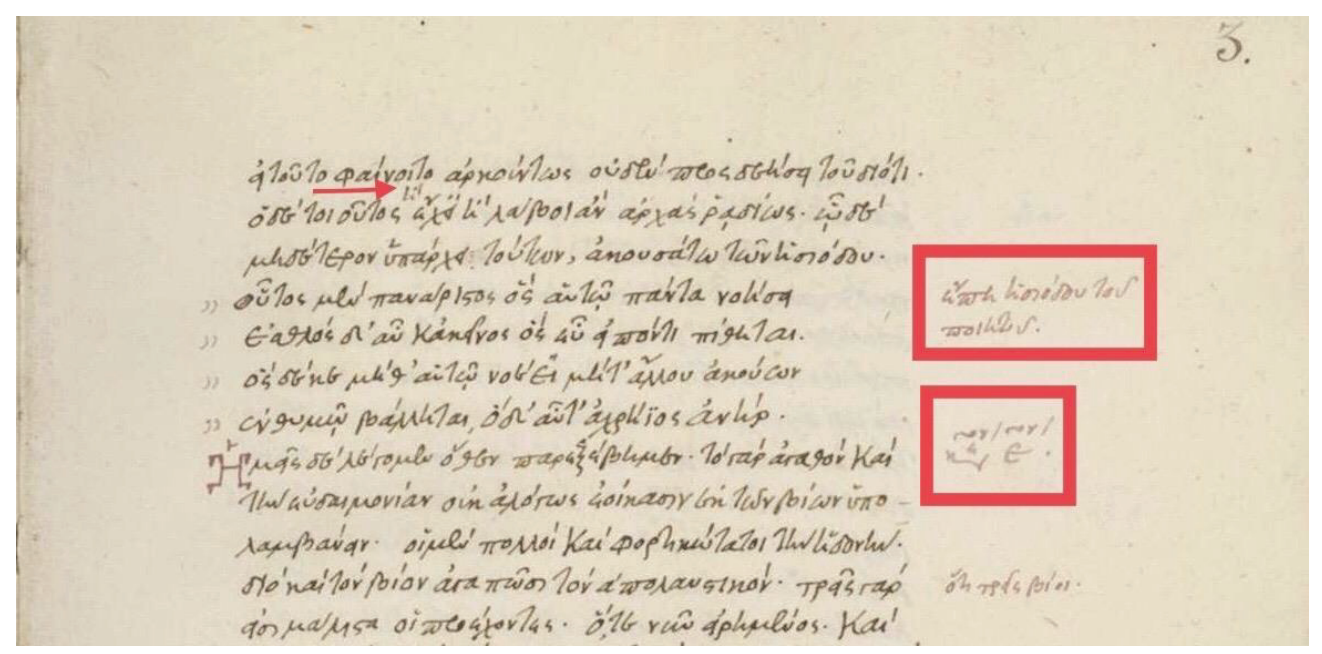

Plate 1. Madrid, Biblioteca Nacional de España MS 4574, f. 3r.

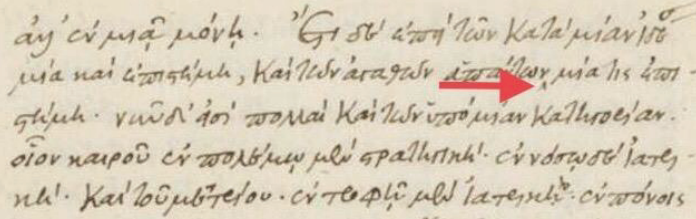

Plate 2. Madrid, Biblioteca Nacional de España MS 4574, f. 4V. 


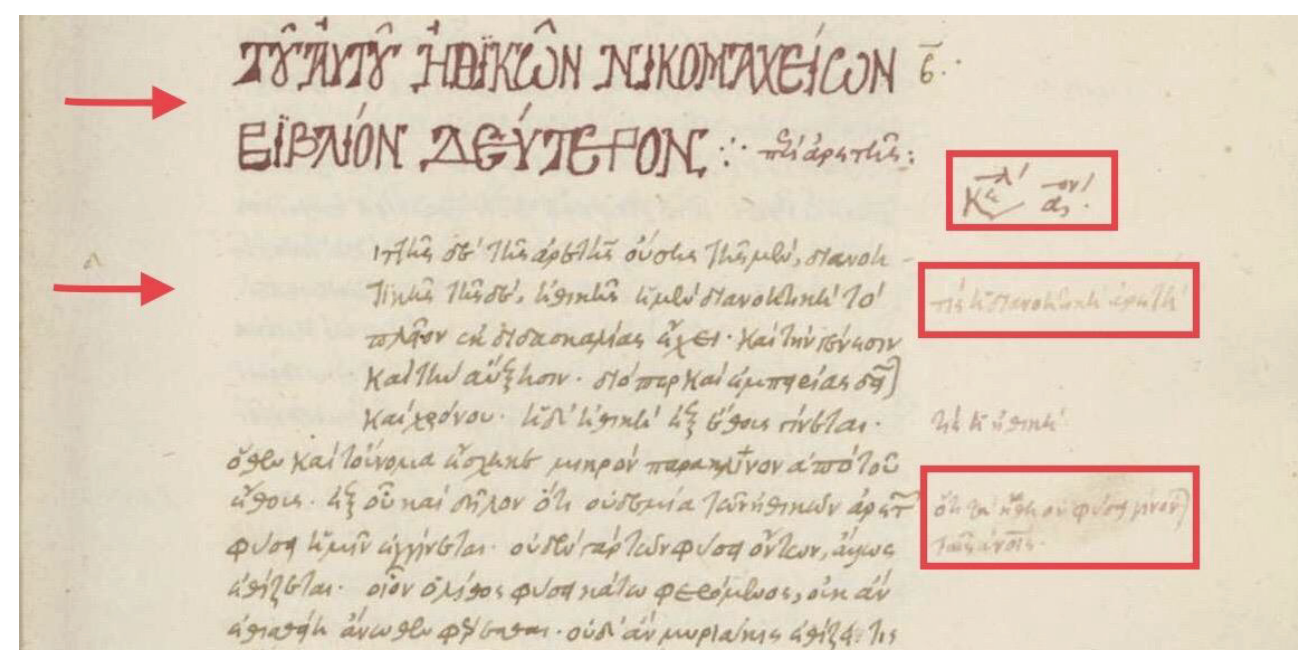

Plate 3. Madrid, Biblioteca Nacional de España MS 4574, f. 12r.

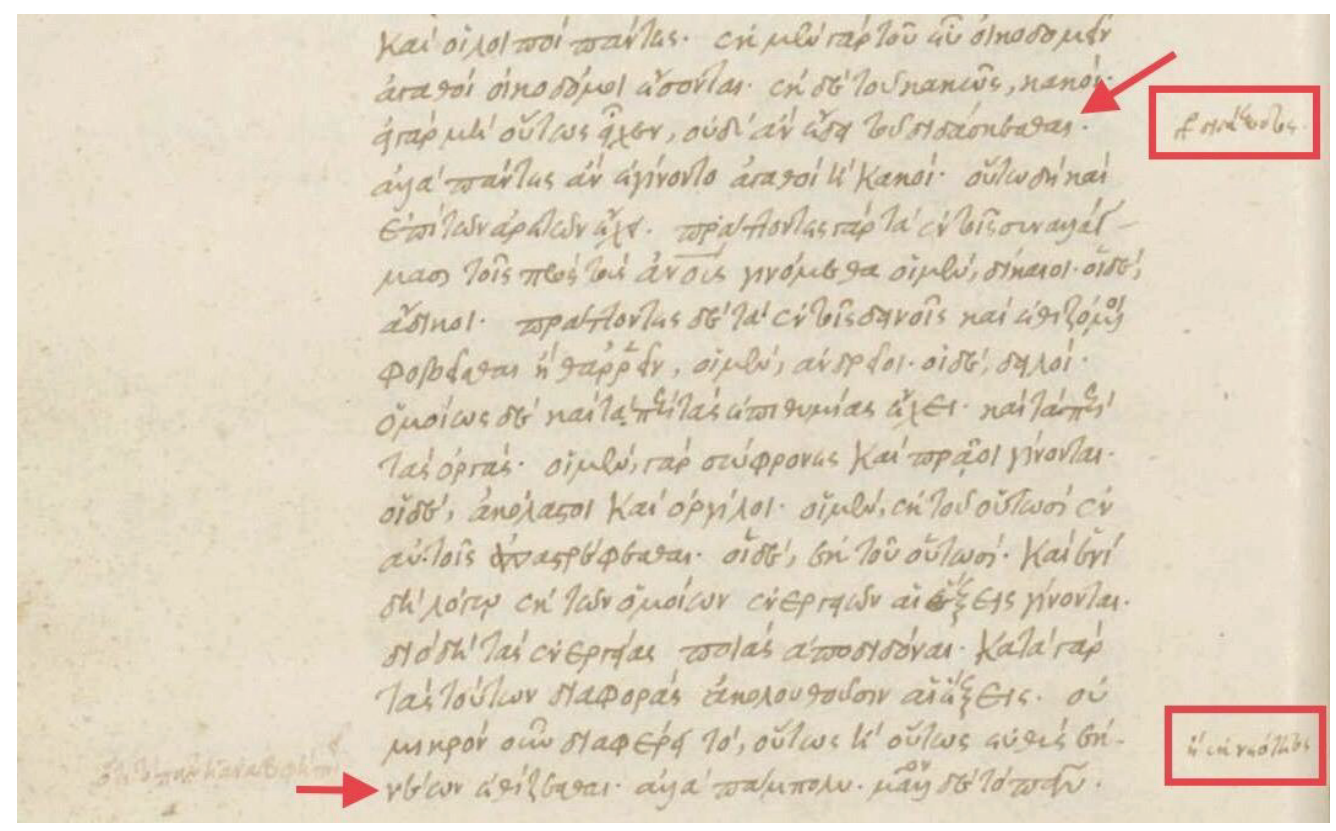

Plate 4. Madrid, Biblioteca Nacional de España MS 4574, f. 12v. 


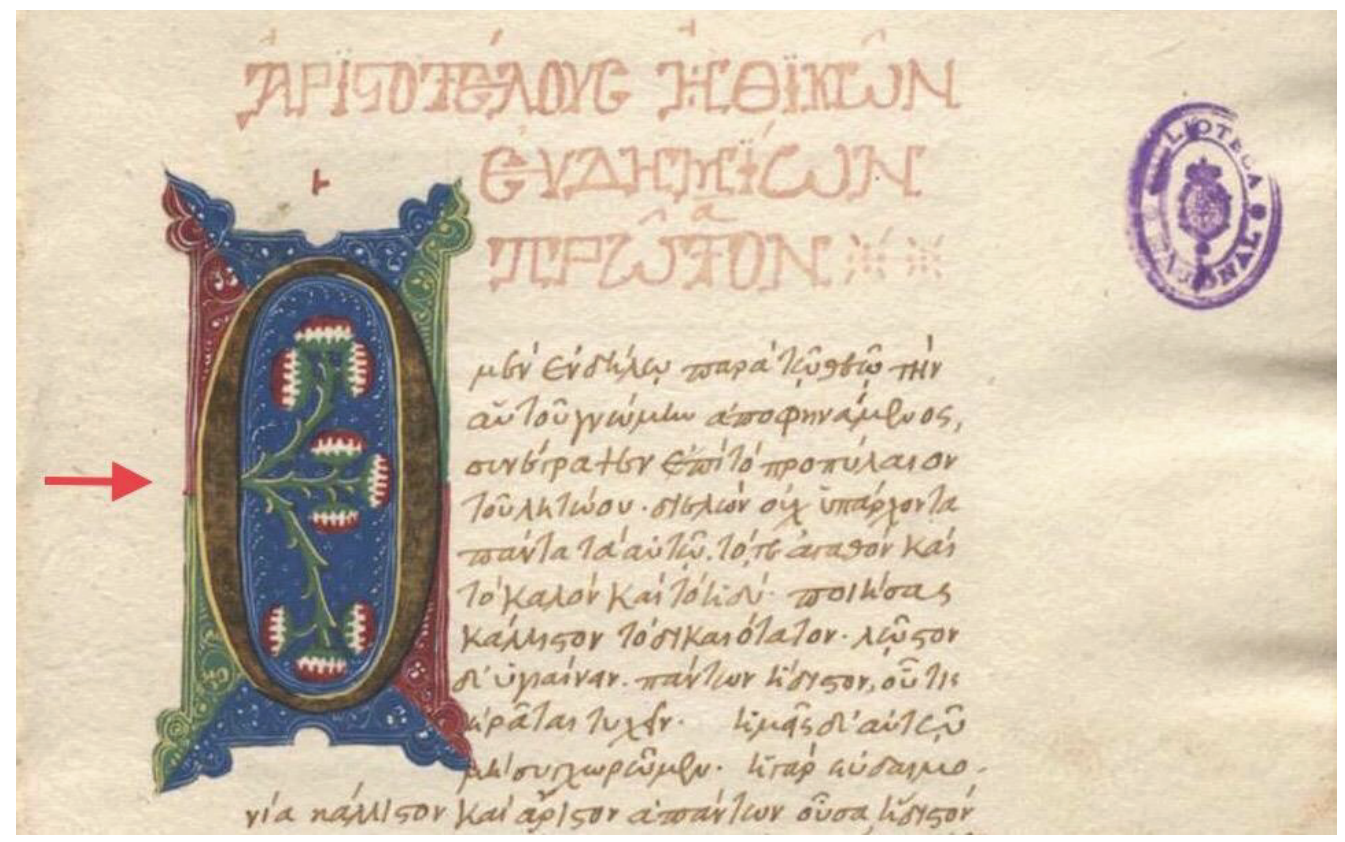

Plate 5. Madrid, Biblioteca Nacional de España MS 4627, f. ır.

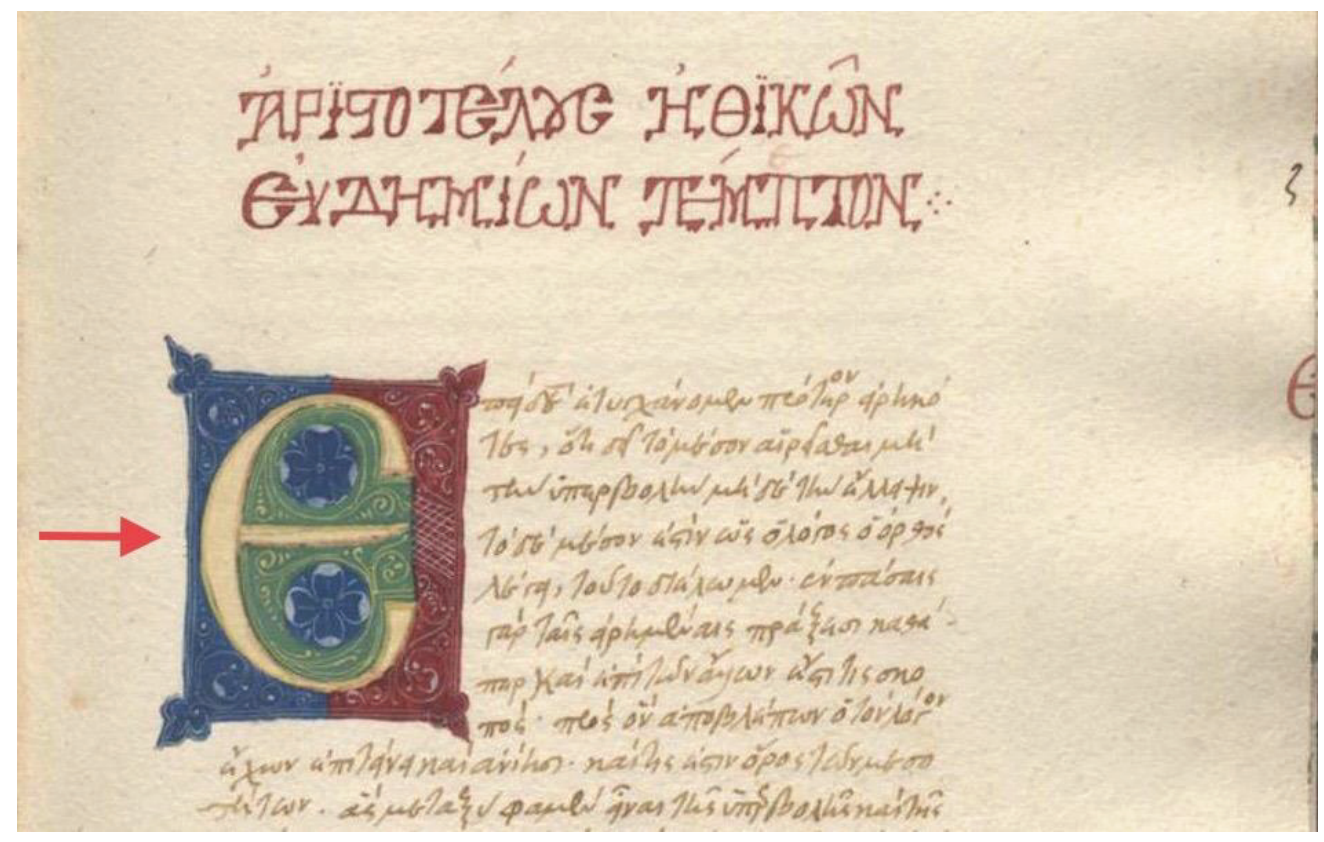

Plate 6. Madrid, Biblioteca Nacional de España MS 4627, f. 48r. 


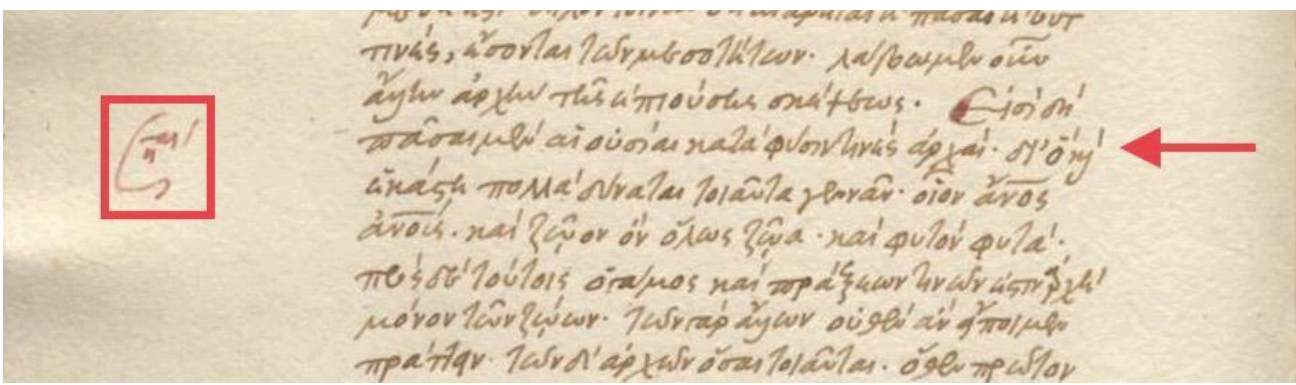

Plate 7. Madrid, Biblioteca Nacional de España MS 4627, f. 15v. 


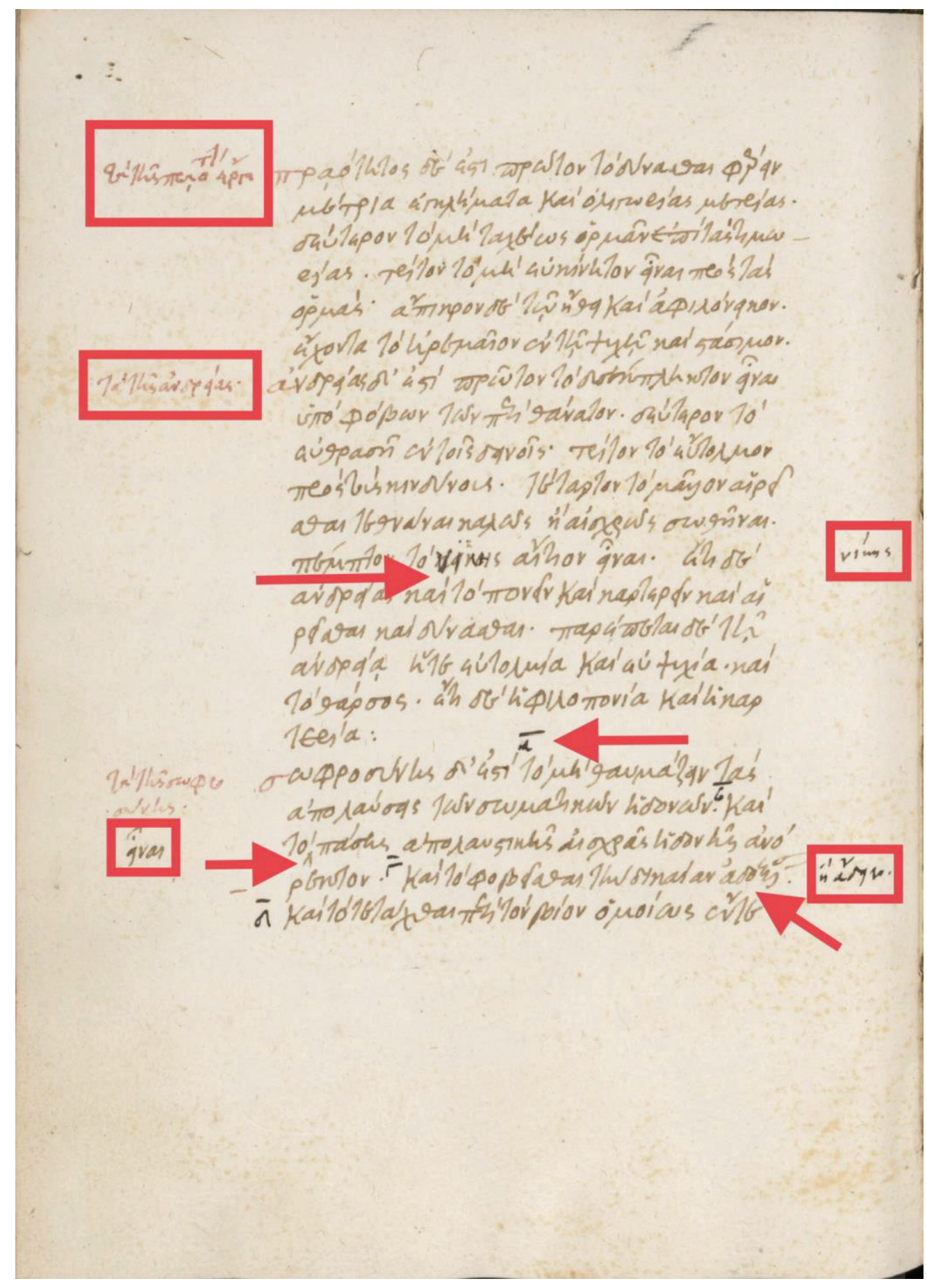

Plate 8. Madrid, Biblioteca Nacional de España MS 463o, f. 47V. 


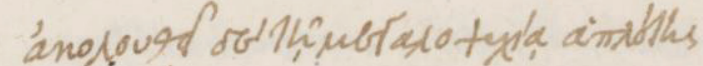
Kaitightora: To

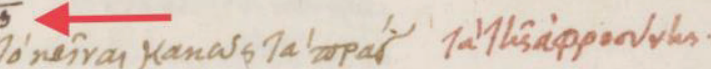

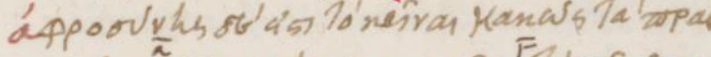
rala. To'poulaubarar rancis. "Io'xpñara

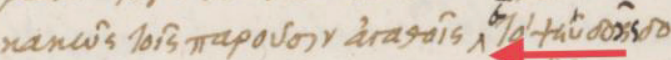

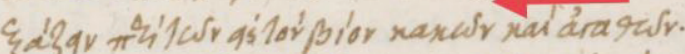

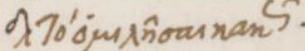

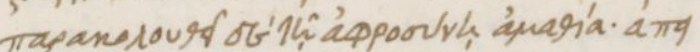

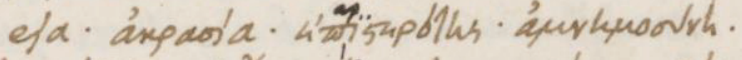

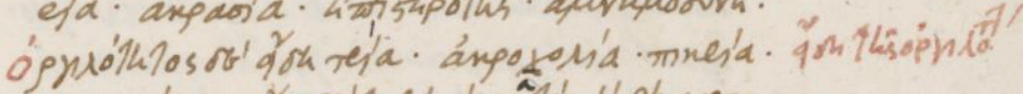

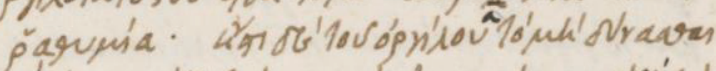

Plate 9. Madrid, Biblioteca Nacional de España MS 463o, f. 49r. 